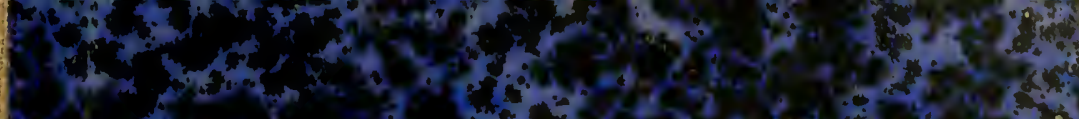

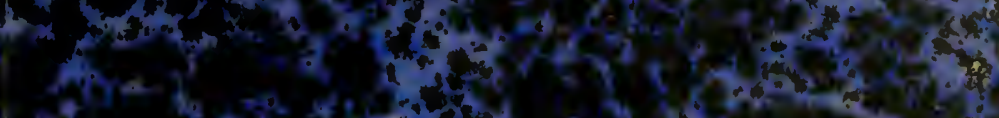
(3.t) C. 3t.

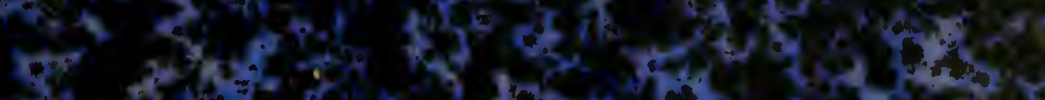

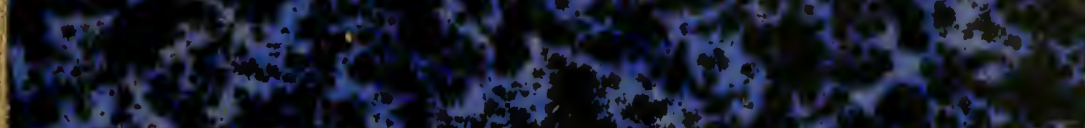

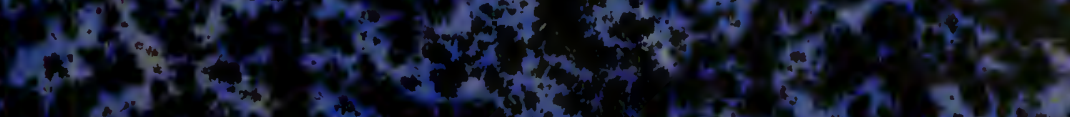

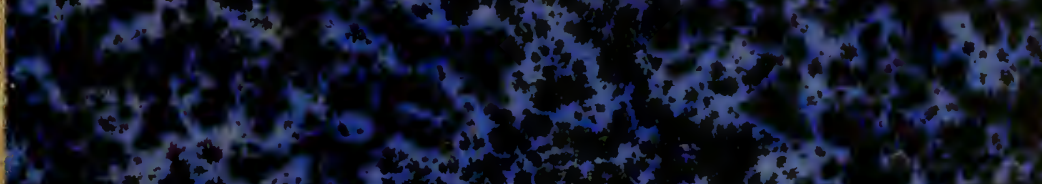
o

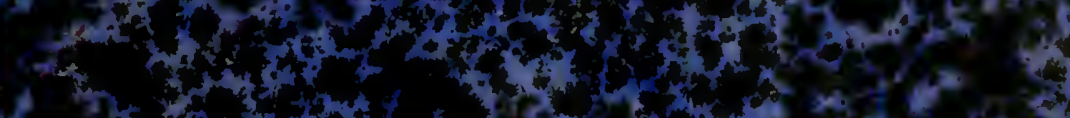

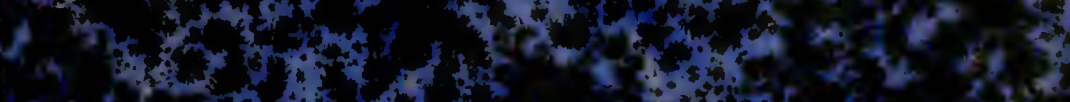
4.

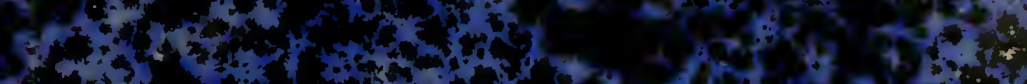

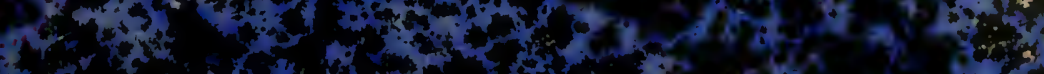

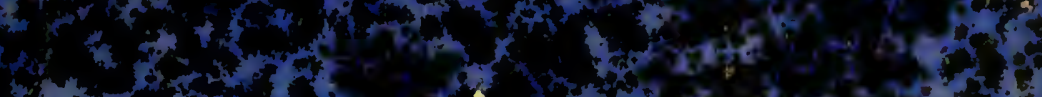

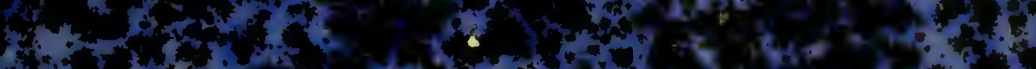
If

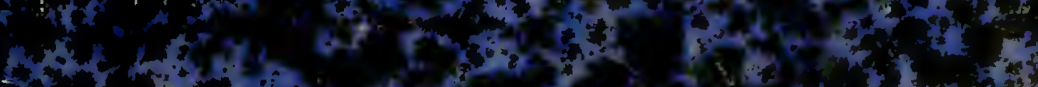

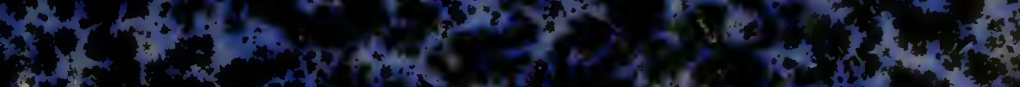

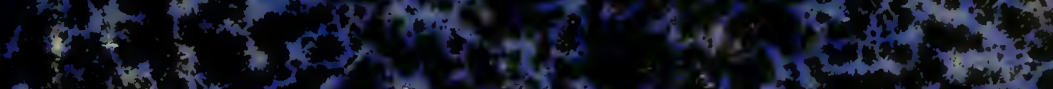

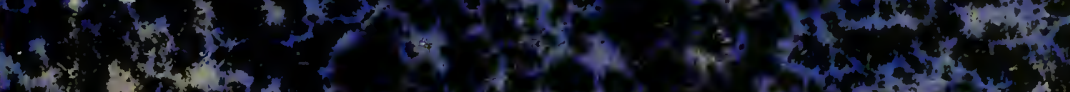

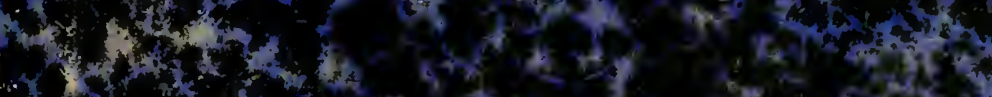

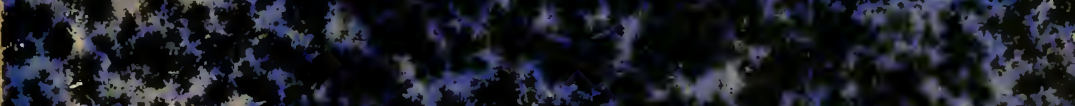

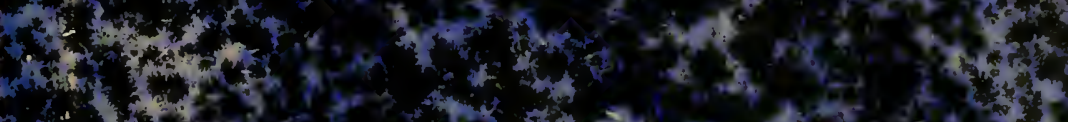
a.

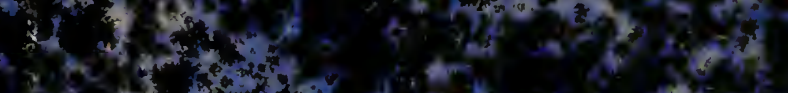

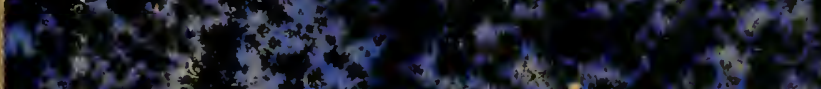

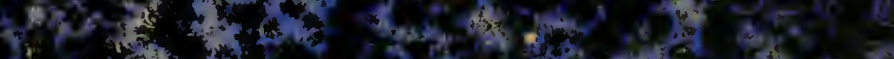

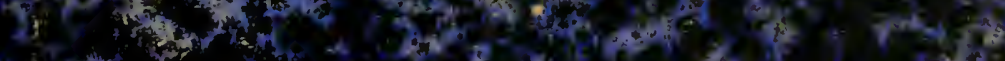

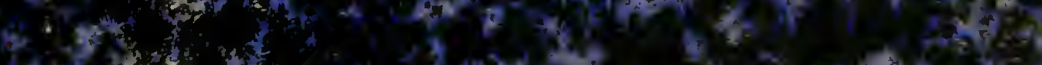

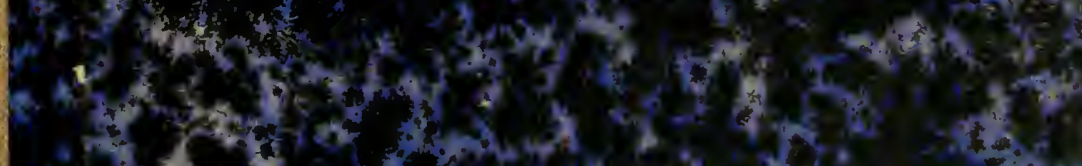

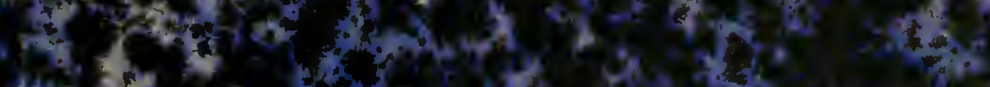

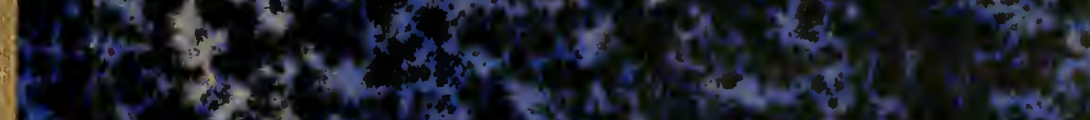

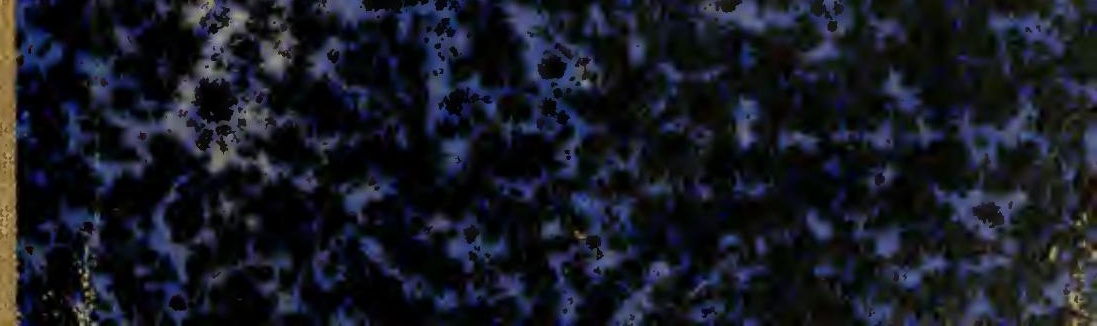




$$
P=-D>37
$$

HARVARD UNIVERSITY.

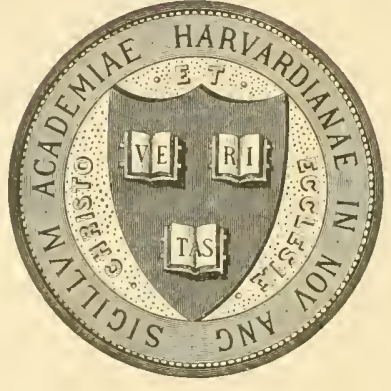

LIBRARY

OF THE

MUSEUM OF COMPARATIVE ZOÖLOGY.

14,589

Brought

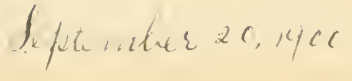




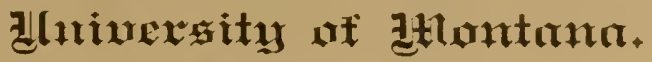

MISSOULA, MONTANA.

\section{SEP 201800}

14,589

\section{THE NEOCENE L.AKE BEDS OF WESTERN MONTANA}

\author{
AND
}

DESCRIPTIONS OF SOME NEW VERTEBRATES

FROM THE LOUP FORK.

A Thesis by Earl Dnuglass, B. S., for the Degree of M. S.

\section{Four Dlates}

JUNE, I899. 


$$
P=-D 737
$$




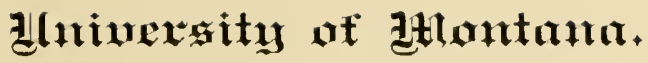

MISSOULA, MONTANA.

\section{THE NEOCENE LAKE BEDS UF WESTERN MONTANA}

\author{
AND
}

DESCRIPTIONS OF SOME NEW VERTEBRATES

FROM THE LOUP FORK.

A Thesis by Earl Douglass, B. S., for the Degree of M. S.

JUNE, I 899 . 


$$
=
$$




\section{SEP 201000}

\section{DESCRIPTION OF LAKE BEDS.}

Since coming to Montana in the spring of 1S94, I have spent mur.h of my time in studying the lake bed deposits in the western part of the state, and in collecting and studying the vertebrate fossils found in them.

These deposits occur in nearly every large valley in the mountain regions. I have myself observed them in the valleys of the upper Missonri (above the region of IJelena), Gallatin, Madison, Jefferson, Beaverhear, Ruby (Stinkingwater), Big IIole, Iell Gate, and IBitter Root rivers, and their tributaries.

Hayden and Peale, in the Annual Reports of the U. S. Geol. Sur. of the Territories for 1871 and 1872 , have given very good general deseriptions of these beds.

These fresh water lakes filled the valleys and at some time, east of the main divide, left only the tops of the mountains standing as islets, long islands, and peninsulas in the waste of waters. West of the diride the land masses were larger.

Though ovel a good share of the area of the ancient lakes there are no good exposures yet it is not a difficult matter to ascertain ap proximately their former extent by the topography of the country and the occasional onterops. The sands and clays that compose the deposits are often grassed over, corered with drift, or entirely washed away; yet in some of the valleys there are good and quite extensire exposures. One strip fifteen to twenty miles long near the Madison forms a miniature "Bad Land."

At one time there was a large irregular shaped lake extending from about ten to twenty miles north of Holena, southeastward, and then southward about seventy miles, to the vieinity of Pony, in Iradison county, on a line nearly west of Bozeman; and, probably, orer the rather low and narrow divide to the south and up the Madison valley about sixty miles farther, making the whole distance between one hundred and thirty and one hundred and forty miles. Its gleatest width from the ricinity of Bozeman to that of Whitehall was at least sixty miles. To the southwestward an arm extencled up the Bearer Head and its trihutaries nearly or quite to the main watelslied of the riocky Mountains south of Dillon. It extended asistwalli to Vilsinia City, and probably across the divide to the east connerting with the waters of the Madism valley, so the Somth Poulder momtain range was an island or peninsula. The Ruby Mountains were 
either an island, or connected by a narrow isthmus at the lower canon of the Ruby with the Tobacco Root range to the east.

East of this great lake across the Gallatin range was another lake in what is now the upper Yellowstone valley. *

To the west of the continental divide another lake began in the vicinity of Butte, extending westward and then northward, occupy. ing the Deer Lodge valley, and perhaps down the Hell Gate to the vicinity of Drummond. There was another smaller one in the vicinity of Phillipsburg on Flint creek a tributary of the Hell Gate. There was also a large lake occupying the Bitter Root and Missonla valleys.

Near White Sulphur Springs in the valley of Smith or Deep liver was a comparatively small lake, belonging, according to Dr. IV. B. sicott, to the later John Day ** and early Loup Fork divisions; while the other beds lelong to the White River and later loup Fork horizons. As the Deep River beds have been studied, and their rertehrate remains described by Cope and Scott, I will confine myself, prin. cipally, to the more extensive deposits in the other parts of the state.

By far the best exposure is in the lower Madison valley. This ralley extends about twenty miles south from the Three Forks. where the Jefferson, Madison, and rallatin rivers unite to form the Missonrl.

On the west side of the river extending eight or ten miles in a north and sonth direction is a series of nearly perpendicular cliffs composed principally of clay, fine sand, volcanic ash and conglomerate, gray in color, but often stained with iron. They are usually soft, yet there are in places some rery hard layers. The river has not cut through the hed so as to expose the rock beneath, but the thickness of the exposme must be at least two hundred feet.

Above these beds, on the east side of the valley, are snfter, marly heds, almost white, weathering into conical hills and bluffs with even. ly sloping sides which have an angle of twenty-fire to thirty-five de. grees. I have olserved no distinct line of separation between these lorls and the ones just described.

Between the marly beds and those above, there is a sharp dividing line and the formations can be distinguished as far as they can be seen. Thre is a sudden change from the white slopes of marl to the cream colored clays and darker sands and conglomerates of the upper beds whose sloping sides are broken by cliffs of harder material. Ther is atso unconformity of erosion. The material of the lower beds

* See Livingston Atlas sheet (Montana).

**W. B. Scott informs me that Matthew helieves the uppermost White River horizon which he has found in colorado corresponds in age to the lower beds in the smith River Valley. 
was laid down, for the most part, in fuiet waters; while a large part of the last described. Was deposited ly rmung streams. The lattro is overlaid by ahont two lumbled feet of cream colored clays. There is no perceptible break but the upper layers are less sandy and are barren of fossils. As will be seen later the fossils show that the lowest bed is White River while the one above the gray marly beds, and probably the last two are Loup Fork.

On top of the benches in many places are hard, brown, rounded rocks, some of them very symmetrical in shape. In places these form a coarse conglomerate. These rounded stones, which average ferhaps three or four inches in diameter, when the softer material is washed away from beneath, slide down the slopes, in some places forming a broad river of them, but flowing only when something dis. turbs some part of the mass. The pelobles are compesed of lard material, mostly quartzyte. They are coated lrown and the brown color seems. to a slight extent, to penetrate the rock near the surface. If the sun appears when they are wot by a shower they shine like polished silver. Possibly thes were deposited here when the Marlison rirer fiowed at this level.

There is a general similarity in the lake beds where I lave examined them yet there are many lncal differences and a considerable lithological variety; so that in nearly every valley one finds something new and interesting. In one place there are large perpendicular seam, of Jasper eutting the hard clay and conglomerate, and carities coated with hyalite; in another, cavities covered with quartz and calcite crystals, the inner ones lined witl a thin coat of quartz, and what were apparently logs and stumps turned into calcite or with alternating con. (entric layers of calcite and quartz erystals. In another place there are what seem to be ancient geyser cones and hot spring deposits, and layers of "petrified moss." On the lower Madison there is much sillel fied woor some of which is rery beautiful. There are also small qustities of fossil wood in other localities.

One almost constant feature of these lake heds is the pure gras volcanie ash occupying one or more layers. On Black Tail Deer creek is a stratum of this material which is seventy or eighty feet in thickness and weathers in a peculiar way. There are pillars standing (n) the slopes and architectural forms resembling marble temples.

In many of the valleys the overlying material is incolerent sand and gravel. and this so cover's the other beds beneath that there are frw good exposures. Then, too. grasses and shruhs cover the slopes and henches thus preventing a study of the strata.

As stated in the Three Forks Atlas sheet the heds are. in some places rapped with hasalt. I have not uow data sufficient to settle positively the duestion as to the age of these lava flows. whether be. 
fore or after the deposition of the Loun Fork deposits; but, julging from the character of the strata in the midalle valley of the lauby river, I think the basaltic. How that forms the platean between this river and Black Tail Deer creek vverlies the loup Fork. West of Jillon and sontl of Algental are gray cliffs of what is probably Loup, Fork, capped with way lava in layels a few inches thick, showing many successive llows. The platean divide between the Ruby and Madison rivels is apperl by basalt sereral lumbled feet thick (See Three Forks Atlas sheet U. S. Geol. Sur.). Aroumd Virginia City this lava is seen to overtie the lake beds the tops of which reach an altitume of (i200 foet. Over this the lava cap leaches an altitucle of 7000 feet: but farther south near Oll Baldy the height is alout stoo feet. It seems likely as will be seen latel that at one time the waters of the lake extended orer this divide into the upper Madison valley lake thus making one vast irpegular lake oceuping the valley of the upper Missonri alove the region north of Helena, and all the tributaries Howing in above that place.

Tsually the Loup Fork beds are nearly horizontal but the White Fiver beds are often inclined at a considerable angle sometimes as higl as thirty-live legrees. It is erident that during the White River periol the ralleys occupied nearly the same position as at present, that in these valleys sediment was depositer to a considerable thickness: the lakes were then drained and a large part of the sediment remored, leaving benches and bluffs in more protected ulaces as at the present time. The drainage again being intercepted in Loup Fork times, lakes were formed once mole and new deposits formed over the old; then the lakes were again drained and erosion removed a great lart of these reposits. It must not be forgotten, howerer, that some of the langer valleys were probably not erenly filled and the centers wore left as tepressions, the bulk of the deposits being dropsited nèarer shore.

While the White River deposits were being eroderl the lake in the smith river valley was formed. This was probahly dry land again before the latel Loup Fork lake was established. Srott has ascertained by a study of the rerteluate fossils from the smith river region that there are here two distinct horizons; and my rollection seems at present to indicate that there were at least two in the other valleys, both distinct from those on Smith river.

Thomgh these Viocene deposits are geologically moderu, yet they must represent, lumanly spealking. a vast lapse of time. Peale estimates the thicknoss in the Gallatin and Madison ralleys to be abont 2000 feet or more. The area of drainage was small. probably not larger than the whole area of deposifion. The streams were short. and it evidently trok a vast amount of time for the small deltas to push 
themselies out into the large and deep lakes until a good portion wath dry land or marsh. Then eame a periog of dhatulge and erosion which wats perhaps as great. As this was repeated, the length of time was certainly long enough to malke sereral almost emolete eluanges in the species of higher animals.

The geological age of the berls outside of the smith river valley has been a matter of doulit; and so far as I have been alole to ascertain, few fossils had been collected from them. If yyden and Peale called all Pliocene without distinction. In the Jefferson valley IIatlen dis. covered what Lady called Anchitherium and a speries of Helix. *

Leidy described the former under the nime Anchitherium anceste.** This I believe to he a Protohippus as I have the lower jaw, with teeth that cannot be clistinguished from that described by Loidy associated with part of the upper jaw and teeth of a I'rotohippus from near 'Townsend.

Feale in the Three Forks atlas sheet sars: "In the summit of the Madison blufts, in a layer of gray conglomerate sandstone numerous fragments of fossil bones were found, which were identified as the same as were found in other localities in the Pliohippus berds of Narsh."

In no place have I found fossils abundant, yet there has been enough to arouse and sustain the most lively interest. No wreat quantity of any one species was found and the collection presents a large nnmber of species in proportion to the amount of material.

Besides the bones mentioned by Peale, teeth and jalls of two or three mastodons and a skull of Procamelus were found by ranchmen, but so far as I know they have been preserved only as curiosities. The Procamelus skull was purchaser, and it is now in my collection.

I give on the next page a table showing succession of strata as exposed on the lower Madison. with list of the fossils, so fal as have been determined, that have heen ohtained at this place, and from the same horizon in other localities in the state.

There is a considerable difference in species betwen the Loup Fork of this region and that of other localities, but the difference is probably one of locality lat ther than age. There was, I judge, as great a difference in the animal life between this mountain region and the region east of it as there is to-dlay. Prohaluly the Montani specios more resembled those found near Cottomwond creek in Oregon. Although the material has not been fully worked ny. there are some species that are especially interesting as they show the close relationship between the fauna of this country and that of the corresponding

* Sixtlr Aun. Rep. T. S. Geol. Sur. Terr.. p. 6ís.

**Monograph I, I'. S. (Geol. Sur. Trorr.. I). 2.1. Plinte XVTI. 
Table Showing Divisions of the Miocene.

\begin{tabular}{|c|c|c|c|c|}
\hline Age & & $\begin{array}{l}\text { Estimated } \\
\text { Thickness }\end{array}$ & $\begin{array}{l}\text { Character of } \\
\text { Surata. }\end{array}$ & $\begin{array}{c}\text { Fossils. Newly named } \\
\text { species italicised. }\end{array}$ \\
\hline$?$ & $\begin{array}{c}\text { No. } \\
5\end{array}$ & & $\begin{array}{l}\text { Smooth rounded } \\
\text { pebbles }\end{array}$ & No fossils. \\
\hline & $\begin{array}{c}\text { No. } \\
4\end{array}$ & $250 \mathrm{ft}$. & $\begin{array}{c}\text { Rather soft cream } \\
\text { colored clays and } \\
\text { fine sand. }\end{array}$ & No fossils. \\
\hline 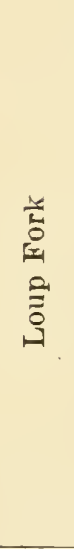 & No.'3 & $\mathbf{2 5 0} \mathrm{ft}$. & $\begin{array}{l}\text { Clay, sand and } \\
\text { gravel. Some- } \\
\text { times quite } \\
\text { hard. Layers } \\
\text { of volcanic ash. }\end{array}$ & $\begin{array}{l}\text { Sciurus, Castor, Mus? Fe] } \\
\text { is, Canis, Aelurodon saevus, } \\
\text { Mustela, Chalicotherium? } \\
\text { A phelops, Anchitherium mini- } \\
\text { mus. Protohippus fossulatus, } \\
\text { P. speciosum, P. sejunctus, } \\
\text { Hippotherium isonesum, H. } \\
\text { relictum, Merycochoerus altir- } \\
\text { amus, M. mudisonius, .I. com- } \\
\text { pressidens, Dicotyles, Gomph- } \\
\text { otherium serus, Protolabis } \\
\text { montanus, Procamelus madi- } \\
\text { sonius, P.occidentalis? P.lacus- }- \\
\text { tris, Blastomeryx gemmifer, } \\
\text { Cosoryx necatus, C. furcatus, } \\
\text { C. agilis, Palaeomeryx ameri- } \\
\text { canus, P. madisonius, Masto- } \\
\text { don, Testudo nebrascensis, } \\
\text {-Birds, Clams, Fossil wood. }\end{array}$ \\
\hline
\end{tabular}

(Snith or Deep River Beds)

\begin{tabular}{|c|c|c|c|c|}
\hline 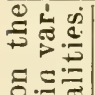 & No. 2 & $400 \mathrm{ft}$. & $\mid \begin{array}{c}\text { Marl volcanic } \\
\text { dust; soft lime- } \\
\text { stone \& fine sand. }\end{array}$ & Snails. \\
\hline 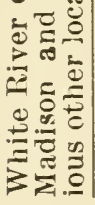 & No. 1 & $200 \mathrm{ft}$. & $\begin{array}{c}\text { Gray and yellow } \\
\text { clay. sandstone } \\
\text { and conglomerate } \\
\text { Hot spring de- } \\
\text { posits. }\end{array}$ & $\begin{array}{l}\text { Castor, Hyaenodon, Hyraco- } \\
\text { don, Aceratherium, Colodon } \\
\text { dakotensis, C. procuspida- } \\
\text { tus, Titanotherium, Meso- } \\
\text { hippus, Oreodon culbertson, } \\
\text { O.gracilis, Agriochoerus, Poe- } \\
\text { brotherium, Turtles. }\end{array}$ \\
\hline
\end{tabular}

age in Europe. The discovery of Palaenmeryx has been predicted by Cope and suspected by Scott, but it has now become nearly a certainty as I have found the inferior dentition-exclusive of incisors and ca1:ines, - of one species, and the molars of another, both having the characteristic Palaeomeryx fold.* I have also discovered a second American species of Anchitherium (using the term in the restricted sense in which it is used by Scott); but it is much smaller than the

- See note under Palaeomeryx. 
European or Smith river (Deep river) species. Tliere is also a tooth like that of Chalicotherium.

I give below a table complete as I can at present make it, showing the faunas of the four different horizons of the Neocene of Montana. The lists under Deep River beds are taken from Scott's Man:malia of the Deep River Berls.*

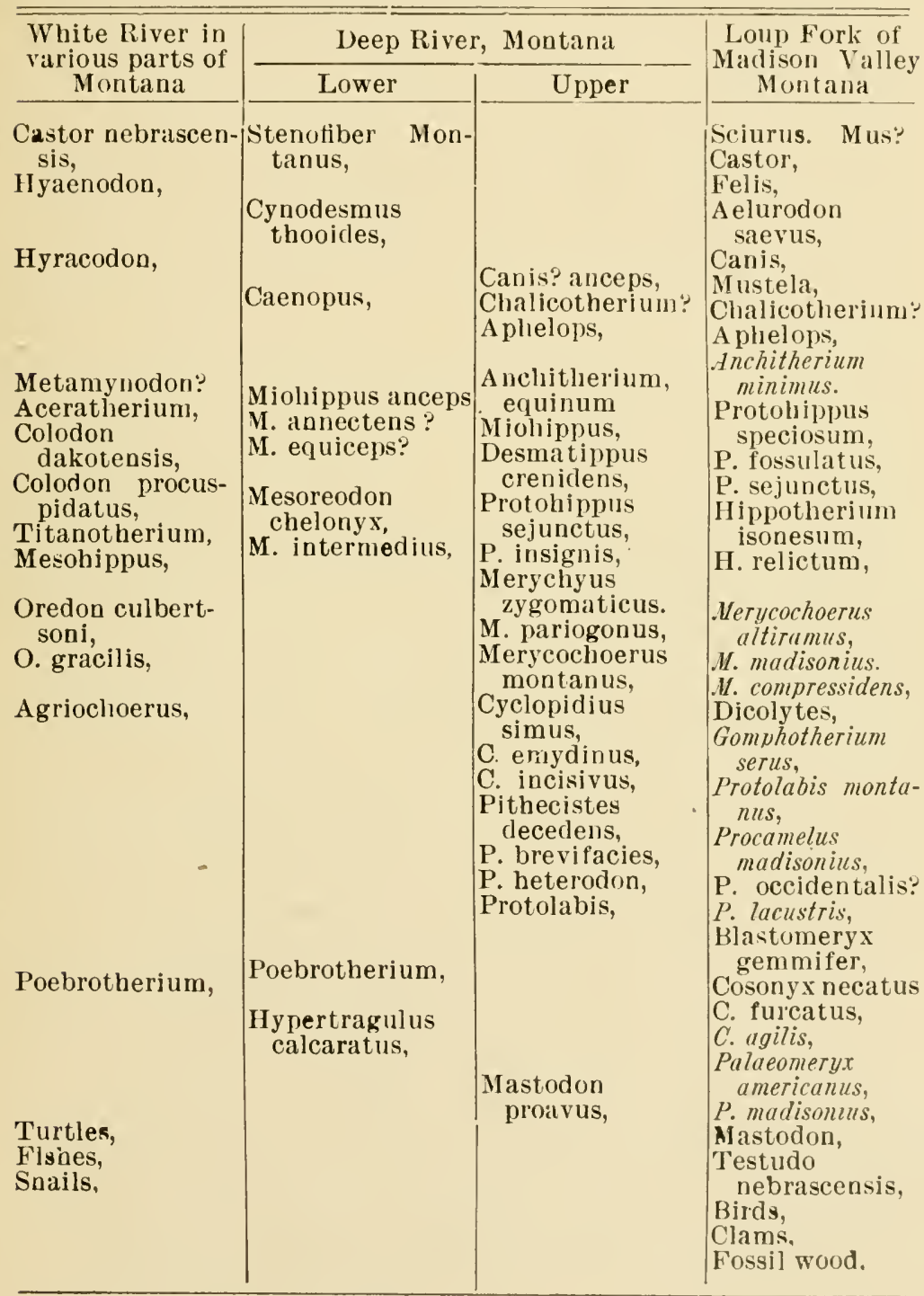

*Am. Phil. Soc. Oet., 1893. 
The greater part of my collection was obtained along the bluffs bordering the lower Madison valley on the east. These extend north and south for a distance of fifteen miles, being in some places seren linnlred feet or more in height. Though there are no permanent streams entting throngh them, occasional heary rains and melting snows have carved many raviues into the soft material, and exposed nuch of the rock. On the northern slopes grass and trees sometimes grow in abundance, while the hot dry southern slopes only support dwarf cedars, seattered, hardy shrubs, cacti, and oeeasional bunches of grass. The conditions are farorable for the finding of fossils if they oecurred in any great number.

All the Madison valley fossils with the exception of a few teeth and bones, and the sknll and jaw of a rodent taken from the White liver beds were found in the Loup Fork strata.

I have found a limited number of fossils from both horizons in wiclely separated localities from near Lima ou the Red Rock to the vidinity of Townsend on the Missouri.

Sontheast of Dillon is an exposure of a few rods in extent where framents of teeth and bones were quite numerous. Prof. E. A. Steere, then principal at Dillon, discovered this locality in 1894, and obtained from it parts of upper and lower jaws and teeth, with other bones, of a species of Protohippus.

West of the main divide* ouly a few fragments have been found, among which are a small piece of mastodon tooth, the distal end of the ulno-radius of a camel, an incisor of a rodent-probably sciurus, and a few pieces of fossil wood, found in the Bitter Root valley. Some who have dug wells have found fossil wood and fragments of bone; but, so far as I have examined them, these beds are very poor in fossils.

There were lakes west of the monntains that existed in later times than the others that have been described. In the latter region ther are few, if any, places where the ancient shore line can be plainly traced. In the Missonla and Bitter Root valless on the mountain sides and along the foot hills are level lines or small terraces, evidently shore lines, formed by the dashing of waves against the momtain sides. These can he nicely sturlief around Missonla. The I niversity buildings stand at the foot of a steep mountain slope, and on this slope about sixty of these lines can be counted, beginnlug neil the foot and exteuding upward, perhaps a thonsand feet. The same is seen on Mt. Jumbo, and on the hills north of Missoula. They

* Since this was written a small Lomp Fork exposure near Drummond has yielded some excellent specimens. Sereral White Rlver fussils were found near the same place. 
are also found along the Bitter Root. Prot. Whorl says they are still plainer in the region of Flathead Jake. These lins's ar always lerel

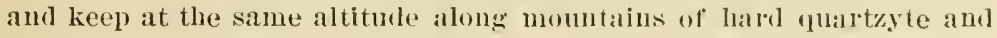
hills of loose gravel. It is difticult to see low these lines an be preserved so long where the material is soft anel incoherent; and one is led to believe that the water cut with romparative rapidity through lts barrier in geologically recent times. When the water reached its highest point it remained for a long time at ar near the same level. Frof. Bailey Willis of the U. S. Geological Surrey who lias risited this region suggests the idea that this was a I'pistocene lake dammed by a glacier. In the Missoula valley are soft laninated elays quite different in appearance from these from which fossil bones were found.

The lake beds lie in contact with all the older formations that ocur in the western part of the state-the Archatem, Nlgonkian, Cambrian. Devonian, Triassic, Jurassie, and Cletacenss." The newer beds lie unconformaly on the older-at least in many plares-and in the interval between the deposition of the two the White River beds were tilted and carred into hills and benches and valleys, and the waters covered them again, after nearly all rertebrate life had changed, and a new deposit was made with remains of a later fanna entombed in it.

The most of the remains found are mammals and turtles, though there are a few fragments of bird bones, representing two or three species. Many snails and a few clams have been collected but have not been determined.

I have had time to study and describe only a small portion of my collection, and then under ciremmstances not the most farorable: though the young and growing University of Montana has done all it could to help me. It has been ny effort to make as few mistakes as possible, yet, as cireumstances have compelled me to work alnne, isolated from other collections and libraries complete with the literature neerled, it is impossible that no mistakes shonld be made. So I ask the kind indulgence of those older in the work and more farorably situated. I think it better to do the best I can than to leare other workers in perfect ignorance of what is found lere.

It conld hardly be expected that in the formation with fossils so much resembling the Loup Fork of Nebraska there should he so many new species as I have described. I late described none however that I conlel classify with the spercies alrealy found; though it in sometimes difficult to settle the matter by the short descriptions and

* For general history of these lake hasins see Iivingston and Three Forks folios of the U. S. Geotogieal surey. 
measurements without illustrations that have sometimes been given. I recognize the fact that species making is only the beginning of the work of the paliontologist, lont it is the beginning.

The fossils described were found by myseif with the exception of one, for which due credit will be given in the froper place.

Though this is only a preliminary paper, and I hope in the near future to publish something more complete, I wish to heartily thank those who have taken an interest in the work without whose help I conla not have even done as well as I have done. Especially am I indebted to Dr. Oscar J. Craig and Prot. Fred D. Smith, of the Iontana State University, who have takell such an interest and done si) much to help me in $m y$ work; and to r'rof. M. J. Elrod for his con. siant enthusiasm, encouragement, and practical assistance in more ways that I can mention. To Dr. W. B. Scott, of Princeton UnlVursity, I owe a debt of gratitude for his generosity and willingness at all times to give advice and assistance. My friend Mrs. H. C. Irish, of st. Louis, Mo., inked the drawings, lut she is not responsible for any incorrectness in them. To the many others who have given so much help and shown so much kindness I can only express my. gratitude in a general way.

\title{
DESCRIPTIONS OF SPECIES.
}

\author{
ARTIODACTYLA. \\ GOMPHOTHERIUM SERUS, N. SP.
}

Plate I.

This species is represented by the anterior part of a mandible, with alveoli of incisors and canine, the coossified symphysis, a first and secoidd premolar neary complete, a broken third premolar, a complete fourth premolar, and a small portion of the first molar. One side of tic mandible is broken back of the symphysis, and the other below the first molar.

The s.mphysis is rather long and completely coossified. The incisors were large. apparently decreasing somerwat in size from the first to the third. The canine was close to the third incisor. The foramen mentale is helow the front part of first premolar. Premolar 1 is a simple cusp, but with two strong roots. It is placed nearly eifually distant between the canine and the second premolar.

From premolar 1 the upper border of the ramus rises gently and then more abruptly to premolar 2. The second premolar is compressed laterally with a longer cutting edge but is only a trifle longer at the base than the first. Premolar 3 is considerably larger than premolar 
2, and premolar 4 still larger than premolar 3 . The last premolar is mueh like that of Procamelus occidentalis Leisly, and of $P$. lacustris to be deseribed later. 'T'le ramus is rather slim. The incisors were reearly proeuntbent.

Found by myself in a clay eliff in bluffs on the east side of the Madison valley, Gallatin Co., Mont.

\section{MEASUREMENTS.}

M.

Length of diastema between canine and first premolar.... . .015

I.ength of diastema between first and second premolars.... .017

Length from front of jaw to second premolar.......... .056

I.ength of premolars 2,3 and $4 \ldots \ldots \ldots \ldots \ldots \ldots \ldots \ldots \ldots \ldots \ldots .029$

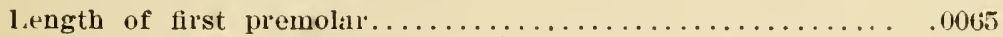

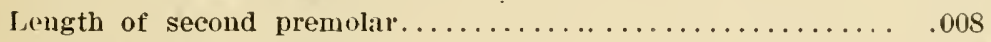

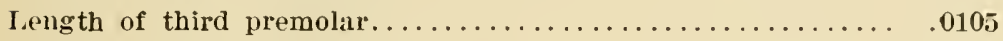

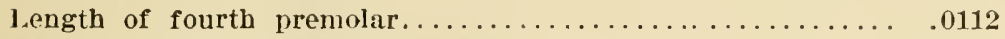

Depth of ramus beneath premolar $2 \ldots \ldots \ldots \ldots \ldots \ldots \ldots \ldots \ldots . . \ldots 21$

Depth of ramus beneath molar $1 \ldots \ldots \ldots \ldots \ldots \ldots \ldots \ldots \ldots .025$

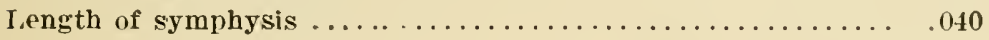

PROTOLABIS MONTANUS, N. SP.

Plate III.

Represented by the entire superior dentition of the right side, with the exeeption of the first ineisor, which has fallen out of the alveolus.

All the incisor's were large, well developed teeth. The first, judging from its alveolus, was as large as the second.

The speeies was larger than $P$. transmontanus Cope* from Cotton. wood Creek, Oregon. I will give the main points of difference be. tween this and Cope's specimen.

In the present species the distance between the third incisor and the canine is twice as great. The height of the crown of incisor 3 is greater. In $P$. transmontanus molar 2 is as wide as long. In the pres $\epsilon n t$ species the anteroposterior diameter is greater than the transverse. This is also true of molar 3. Premolar 2 is two-rooted but is small as compared with premolar 3 , which is a trifle longer than premolar 4 .

In the present specimen there are two first premolars of almost the same shape and size. They are closely crowded. The anterior me is slightly larger than the other, and perhaps should be taken for the permanent tooth. This, measuring from the roots of the teeth.

*Bulletin U. S. Geol. Surr. of Territorles, Vol. Y., No, 1, p. 67. 
wonld much more evenly divide the space between the canine and premolar 2 than in $P$. transmontanus, where premolar 1 is only about a third the distance f'rom the canine. If the posterior tooth be taken as the permanent one, then the conditions would be reversed and premolar 1 would be a little more than a third the distance from premolar 2 to the canine.

Incisor 3 is a long (high) robust tooth, much larger than the canine, but much like it in shape, being pointed, slightly curved forward, and subround in section. The first premolar is smaller than the canine antero-posteriorly, is not so high and is more flattened on the inner side. Only the top is coated with enamel.

Premolar 2 has nearly the form of a lualf cone.There are two slight concavities on the inner side, one anterior and one posterior to th. median line. On the outside of premolar 3 is a small anterior ridge, posterior to this a broad convexity oil the protocone, and back of this a smaller one and a well leveloped posterior ridge.

The molars are so much like those of Gomphotherium cameloids figured by Wortman (Extinct camelidae of North America,*) that if only the molars had heen fonml they would have been taken for terth of that species. The length of the last three premolars and the molars is about one-fifth greater in Protolobis Montanus.

The last two molars liffer from the corresponding ones of P. Trans montanus in being less quadrate, the posterior portion being narrower than the anterior.

Dug from a clay cliff. Miocene lake heds, lower Madison valley, Montana.

Portions of the posterior part of the lower jaw were found, including a mutilated third molar.

\section{MEASUREMENTS.}

Length of dental series from front of base of first incisor.... .1!5

Ibiastema between incisor 3 and canine, lengtl.......... .012

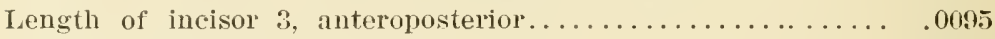

Width of incisor 3 , transverse ................... 009

Diastema between canine and premolar $1 \ldots \ldots \ldots \ldots \ldots .015$ or .021

Diastema between premolar 1 and premolar $2 \ldots \ldots \ldots \ldots .019$ or .014

Length of three contiguous premolars................ 038

Length of Premolar $2 \ldots \ldots \ldots \ldots \ldots \ldots \ldots \ldots \ldots \ldots \ldots \ldots . . \ldots 09$

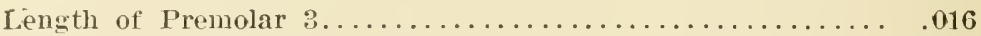

I.ength of Premolar $4 \ldots \ldots \ldots \ldots \ldots \ldots \ldots \ldots \ldots \ldots \ldots \ldots \ldots \ldots \ldots \ldots \ldots . .0148$

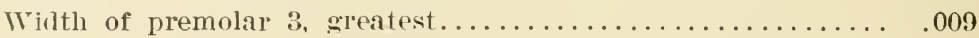

*Am. Mus. Nat. IIist.; Vol. X, Art. VII, p. 118. 


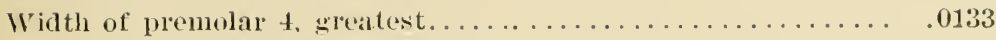

I.ength of true molal series..................... 066

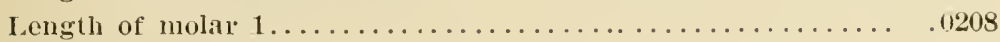

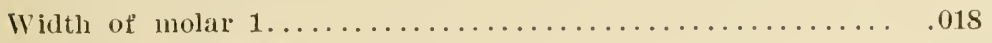

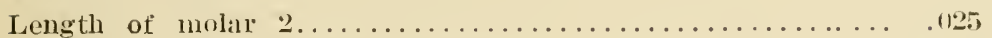

Width of molar 2, gleatest: anterior . . . . . . .

Width of molar 3 , posterior. ................... 017

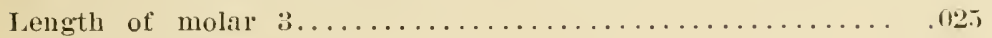

Width of molar 3 , anterior...........

Width of molar 3 , posterior............

PROCAMELUS MADISONIUS, N. SP.

Plate II.

This species is represented by a nearly complete cranimm found by Mr. Dunbar of Gallatin City several years ago, at the foot of the bluffs bordering the Madison valley. The molars on one side had been broken away. I purchased the specimen and on clearing away the hard matrix found most of the cheek teeth on the other side in a good state of preservation. The skull is considerably broken and crushed anteriorly, and the roof of the brain case including the sagittal crest is gone.

The skull differs in many respects from that of $P$. acridentalis Leidy, found by Cope in the Loup Fork beds of New Mexico.

The skull is ahout one-fifth larger than that of Camelus dromedarius and is proportionally broader. The width between the second premolar and third incisor is more nearly uniform; but the palate widens much lack of premolar 4. The malar ridge of the maxilary is almost obsolete; being represented by only a slight narow prominence at the anterior-inferior border of the molar. 'The posterior part of the malar rises to the middle of the orbit; the anterior part does not rise as high as the middle of the orbit-only about one-thira the height. The zygomatic process of the squamosal is higher relatively to the orbit than in Cope's specimen or in the morlern camel and is arched npward being inserted obliquels into the notch of the malar just hack of the lower half of the orbit. Though the skull is broken in this region I judge that the lachrymal simus was small.

The anterior-interior border of the basioccipital is not angulate. but is smoothly rounded, as is also the basisphenoid. In front of the occipital condyle there is a quite high. moadly sloping. transrerse rirlace, divided in the middle by an ollong fossa. Posteriorly this fossa is continued in the form of a suture which is evidently the division line between the imperfectly mossified occipitals. Above the foramen 
magnum on the median line of the occipital is an acute angular ridge.

The foramen infraorbitale anterius opens above the posterior part of the fourth premolar and the anterior part of the first molar.. The palatal notch is $V$-shaped and extends forward as far as the posterior part of the second true molar.

The third incisor is a small tooth in comparison with the canine which is large, robust, and oval in section. The second premolar is (fuite large being about four-fifths as long antero-posteriorly as premolar 3. Premolar 3 is almost the same in form as that of $P$. occidentalis, figured by Leidy. The exterior-anterior part of premolar 4 is slightly concave but back of that slightly convex. In the molare the anterior external risges or horns of the crescents extend somowhat forward, orerlapping the tooth in front; but they do not extend outwarl very prominently. The external ridges on the middle of the (rescents are mostly feetle. The first premolar is one-rooted. It is a little longer than the third incisor.

\section{MEASUREMENTS.}

Total length of skull, ahout...................

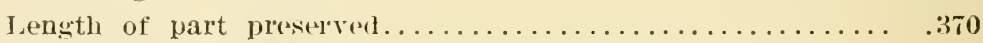

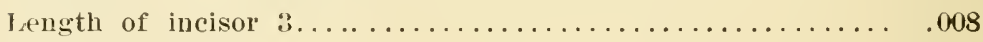

Height of incisor $3 \ldots \ldots \ldots \ldots \ldots \ldots \ldots \ldots \ldots \ldots \ldots \ldots \ldots .012$

Diastema between incisur $; 3$ and annine.............. .014

Length of canine antero-posteriol . . . . . .

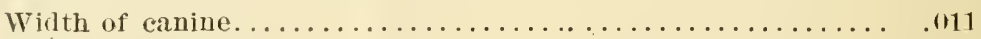

finnine to premolar $1 \ldots \ldots \ldots \ldots \ldots \ldots \ldots \ldots \ldots \ldots \ldots \ldots \ldots . . . \ldots 13$

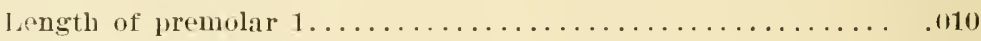

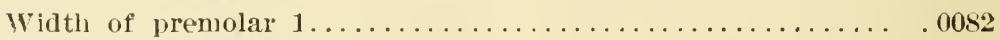

I'remolar 1 to premolar $2 \ldots \ldots \ldots \ldots \ldots \ldots \ldots \ldots \ldots \ldots \ldots . .020$

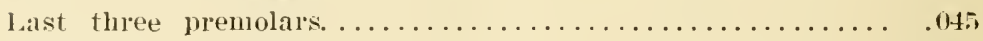

I.ength of premolar $2 \ldots \ldots \ldots \ldots \ldots \ldots \ldots \ldots \ldots \ldots \ldots \ldots . . . \ldots 14$

I.ength of premolar $3 . \ldots \ldots \ldots \ldots \ldots \ldots \ldots \ldots \ldots \ldots \ldots \ldots . .017$

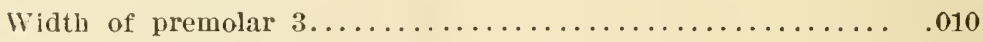

I. ength of premolar $4 \ldots \ldots \ldots \ldots \ldots \ldots \ldots \ldots \ldots \ldots \ldots \ldots \ldots . . . \ldots 164$

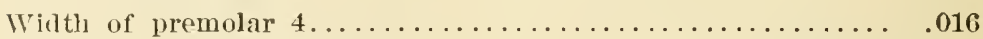

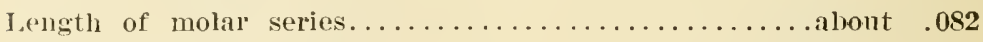

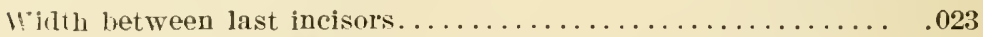

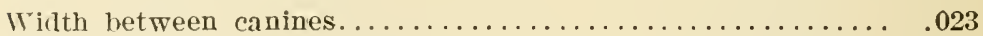

Width between first premolars.................. 023

Width between second lremolars.................. 026

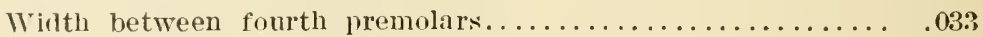

Wilth between second molars, front............... 04:0

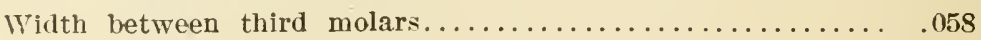


Anfero-posterior diameter of orbit.................. ots

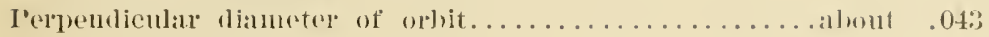

It is possible that this skull may belong to some species the inferior dentition of which has already bere described; but in fles same locility I labe found two rami which l provisionally reler to the same species. These lanli ale diffornt from anything with which 1 am acquainted. It is possible that these two specimens are from distinct speries, hut they are so nearly allike that I prefer to consider them as one nutil other parts are found.

Mandible. The sperimen which l talke as a lower jaw type cousists of a horizontal ramms hroken off a little back of the second molill. with a thind incisol, the first 1nemolar, and the first molar complete, and the larger part of the seroml molar, with parts of alveroli of incisors 1 and 2. of the canine, and complete alveoli of the third and fomth premolats. with a small portion of memolat 4.

The $\mathrm{j} a \mathrm{w}$ is slender. The lower part of the anterior portion in font of the angle of the "hin. is nearly horizontal but slightly conave to a point helow the thirl incisor. Hore there is a rather abrupt upwarl curve, but the exact shipe of this portion is difficult to make out as it is somewhat broken and displarerl. The third indisor is rather broal and thin, concave within, and (onvex on the outsille. It is semilrocmubent, as were also the first and semonl incisols. There is a short diastema betwen the third incisor and the canine, which, judging by the portion of the alveolus remaining. was not a very large tonth. 'The distance between the canine and the first premolar is about 20 11m.n. and the distance from the first to the second premolar is about the same. The first premolar is small and thin with sharp edges and a long backward-colving root. The second plemolar was small and one-rooted. Molar one has a high crown. The foramen mentule is near the angle of the chin, just in allanee of premolar 1 . There is another foramen beneath premolar 8 . The jaw fits fairly well the skull just described.

\section{MEISTREMENTS.}

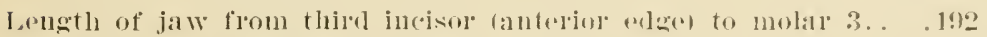

Canine to first plemolar, almont.................... .1120

First premolal to second liremol:1................... .1127

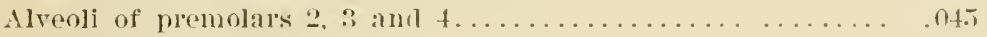

Length of thirt incisol. ...................... 0.11

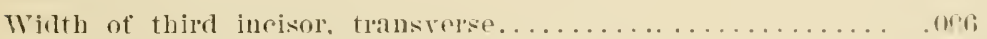

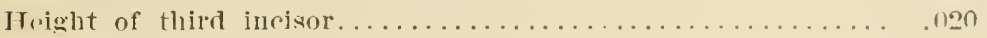


Length of first premolar...................... 007

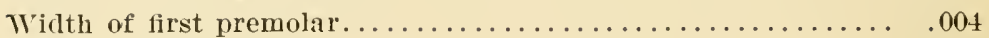

Length of first molar.......................... . 0.31

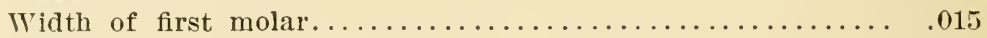

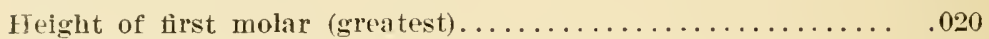

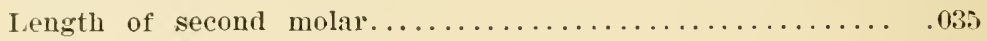

Depth of ramus behind third incisor, about............ 033

Depth of ramus behind premolar $1 \ldots \ldots \ldots \ldots \ldots \ldots \ldots \ldots \ldots . .0294$

Depth of ramus beneath premolar $2 \ldots \ldots \ldots \ldots \ldots \ldots \ldots \ldots \ldots .031$

Depth of ramus beneath molar $1 \ldots \ldots \ldots \ldots \ldots \ldots \ldots \ldots \ldots \ldots .0367$

Depth of ramus under molar 2, posterior part............. .141

Found in clay cliff, lower Madison valley, Montana.

The second jaw fragment contains premolars 3 and 4 and molars 1 and 2 , and a fragment of the mandible. The teeth are large but the ramus is eren more slender than the corresponding part of the one previonsly described. Premolars 3 and 4 are about the same size. The latter has a posterior valley. This tooth does not fill the posterior part of its alveolus. The lower border of the ramus is nearly straight. There is a small alveolus under molar 1.

\section{MEASUREMENTS.}

Premolar 3.

M

Length. . .0185

Breadth .0085

Height. . .013
Premolar 4.

M.

.009

.013
Molar 1.

M.

$.02 S$

.018

greatest .022

Molat :2.

Length of last two premolars and first two molars......... .0965

Depth of ramus beneath premolar 3 , anterior............ 028

Depth of ramus beneath Molar 1, anterior............. 028

Depth of ramus beneath molar 2 , anterior............ 029

Depth beneath molar 2 , posterior................ 032

Found in lower Madison valley, Montana.

\section{PROCAMELUS LACUSTRIS, N. SP.}

\section{Plate I, Figure 2.}

The type specimen of this species is the left mandibular ramus with all the teeth except the incisors. The lentition with the exception of the canine is nearly like that of $P$. occidentalis Leidy. The principal rifferences so far as I can determine are in the smaller and more compressed canine and the depth of the ramus, which is much slimmer tluan in $P$. occidentalis. Premolar 2 is also more robust than in the specimen figured by Leidy. There are some minor differences in the teeth which approach nearer to $P$. angustidens Cope, especially in the 
form of molar 3 and the inner surfice of the molirs; but the specimen is smaller; premolar 4 differ's in widtl; and molar 1 is shorter. I'rom Cope's deseription I judge that the diastemata are slorter.

There is a very large mental formmen, the posterior part of which is beneath the anterior part of premolar 1. It is very deep and oval in shape. There is also a small toramen below the line of contact between premolar 4 and molar 1 . Abont one third the distance from the lower border of the jaw there is a depression extending beneath the last three premolar's and the tirst molar. On the inner side one extends noar the lower borker meler the molar series.

\section{MEASUIEMENTS.}

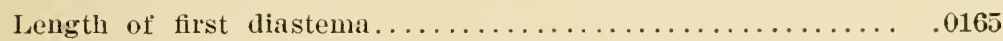

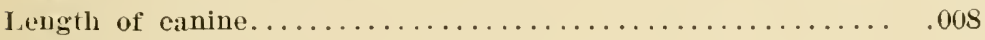

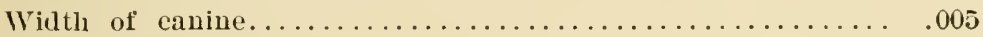

Length of premolar $1 \ldots \ldots \ldots \ldots \ldots \ldots \ldots \ldots \ldots \ldots \ldots \ldots . .009$

Width of premolar $1 \ldots \ldots \ldots \ldots \ldots \ldots \ldots \ldots \ldots \ldots \ldots \ldots \ldots . .0047$

Length of second diastema..................... .012

Length of premolar $2 \ldots \ldots \ldots \ldots \ldots \ldots \ldots \ldots \ldots \ldots \ldots \ldots \ldots \ldots .0121$

Width of premolar $2 \ldots \ldots \ldots \ldots \ldots \ldots \ldots \ldots \ldots \ldots \ldots \ldots \ldots .006$

Iength of premolar $3 \ldots \ldots \ldots \ldots \ldots \ldots \ldots \ldots \ldots \ldots \ldots \ldots \ldots .015$

Width of premolar $: \ldots \ldots \ldots \ldots \ldots \ldots \ldots \ldots \ldots \ldots \ldots \ldots \ldots . . \ldots \ldots \ldots 5$

Length of premolitr $4 \ldots \ldots \ldots \ldots \ldots \ldots \ldots \ldots \ldots \ldots \ldots \ldots \ldots \ldots .0177$

Width of premolin $4 \ldots \ldots \ldots \ldots \ldots \ldots \ldots \ldots \ldots \ldots \ldots \ldots . . . \ldots \ldots$

space ocenpied ly all the premolars................. .064

I.ength of molar $1 \ldots \ldots \ldots \ldots \ldots \ldots \ldots \ldots \ldots \ldots \ldots \ldots \ldots .022$

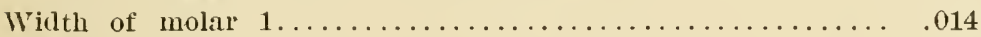

Length of molar $2 \ldots \ldots \ldots \ldots \ldots \ldots \ldots \ldots \ldots \ldots \ldots \ldots \ldots \ldots . . \ldots 263$

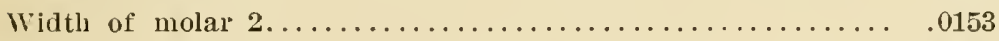

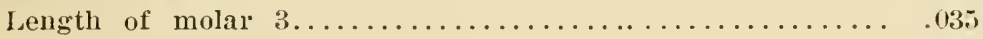

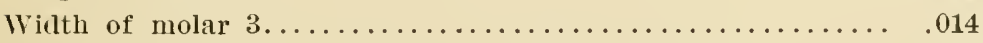

Irength of last three premolars and the three molars . . . . . . . .1236

I septh of mandible below premolar $1 \ldots \ldots \ldots \ldots \ldots \ldots \ldots \ldots \ldots .019$

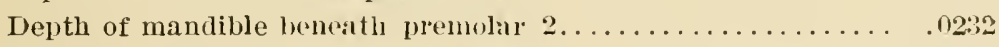

- Tepth of mandible beneath premolar $4 \ldots \ldots \ldots \ldots \ldots \ldots \ldots \ldots .0254$

Depth of mandible beneath molar 1 , anterior............ 026

Depth of mandible beneath molar 3 , front............ .0335

Deptl of mandihle beneath molar 3 , back............ . 16

Found in the Loup Fork beds of the lower Madison valley, Montana.

Besides the camel remains alove described there are many others which will be lescribed in a future maper. 


\section{PALAEOMERYX.}

This genus is represented in my collection by portions of two mandibles, and, probably, by the smperior dentition posterior to the second premolar. One ramus contains the six molars and premolars complete, and is in every essential character like the European Paleomeryx including the characteristic l'aleomeryx fold. The other larger species is represented by a portion of the ramus containing the three molars, somewhat loken, but all showing this fold more plainly than in the precerling from which in it has nearly disappeared-especially on molar 1-on account of the teeth being much worn.

There is now little rloubt that the name Palacomery. as now used applies to American as well as old World species; but this is no cause for surnrise as its discovery has been expected. Though these jaw fragments belong to the genus called Palaeomeryx Jet it does not settle all the points of doubt respecting this genns. A series of upper teeth in my possession correspond in size with the portion of mandible of the smaller species; and though they were not found together, 1 have little dount that they belong to the same species. These upper teeth are rery much like those of Blastomeryx antilopinus Scott, so I think that, as Scott mistrusted, Blastomeryx is really Palaeomery.r, if as Schlosser suspected the type of the latter possessed hor'us, or, if the possession of horns is not o1 generic value.

Note.-Since writing the above I have found a skull, which, though still in the matrix, is evillently almost like Cope's Blastomeryx and is about the same size. With it is a mandibular ramus and other bones. I partly cleared the matrix from the mandible and find that it differs little from the two mandibles here describer except that it is larger than either. This much is certain that the skull of the so called Blastomery. has been found associated with a mantibular ramus that differs in no important particular from the European Palaeomeryx. In camp near Drummond, Mont., July 18,1899.

\section{DALAEOMERYX AMERICANUS, N. SP.}

Plate IV, Figures 2 and 3.

Lower jaw. The horizontal ramus is slim and nearly uniform in width from premolar 2 to molar 3, with a regular downward curve, being in this respect almost like $P$. sansaniensis.* There is a small

* See Fillul's Etude sur les mammifores fossils de Sansan P. 255 P'l, 26. 
mental foramen a little in advance of premolar 2. From ln frout of this foramen a depression extends backwath nearly parallel with the inferior and superiors borders of the lamms, to where the ramus is boven off beneath nolar 3. This depression is nearer the inferior margin, heing about one-third the distance from the interior to the smperior horlers. In front of premolin 2 the nuper margin of the jaw slopes downward to where it is broken. Looking from alove the ramms is slightly sigmoin.

Premolar 2 is much like the corresponding tooth in $P$. sansaniensis On the anterior-interior fare of the tooth is a coneavity looking inware and upwald. The protorone on the inner fare is nearly conical. It is joined on the anterior-external sille by a sharp ridge forming the outer bomnlary of the anterior depression. Opposite this on the posteriorinternal side of the protocone a sliort linge joins the two posterior lobes, or comnects with the anterior hor'n of the crescent. The valley between the limbs of this erescent looks more backwart than in P'. sansaniensis. This is also true of premolar.3. In the latter tooth the two anterior lobes are more separated. that is. form a greater angle, than in the specimen figured ly Filhol, in this respect being more like premolar 4 than in Filhol's specimen. In the American specimen instead of there being an enciosed depression on the posterior part of the tooth there is a gully opening invard. In premolar 2 the middle lobe is directed oblipuely hackward as in P. sunsaniensis. This lobe in premolar 3 is directed forward. Premolar $t$ is little different from Filhol's specimen except that there is a narmow gully opening inward which wonle be obliterated on forther wear. Premolar 2 is slightly, premolar 3 more, and premolar 4 considerably worn; while molar 1 is much worn, molit 2 less and molar 3 only slightly so.

The enamel is smooth on the intrior and somewhat rugose on the outside, but more especially so on the ontside of the true molars.

\section{MEASUREMENTS.}

Premoliar 1. Premolar 2.. Premolar 3. M. II. M.

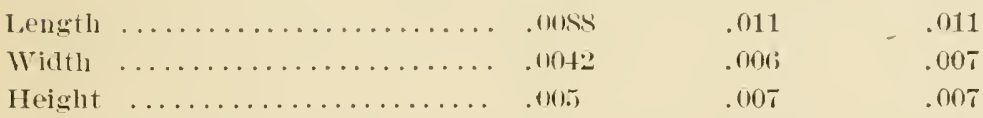

On areomut of its worn condition the anterior enamel lake in molar 1 is party obliteraterl. making fwo sulall ons. 'lle enamel of the small meflian external lohe is rontinuons with the posterior onter crescent. This reserent is still entirely separated on the grinding stlrface from the rest of the tooth, lut a little mole wear would make it confluent with the posterior internal erescent on the posterior internal 
angle of the tooth. The Palaeomeryx fold on account of the worn condition of the tooth is represented by only a slight deflection of the enamel. There is a cingulum on the auterior outer part of each molar.

In molar 2 the Palaeomeryz fold is seen as a slight bulging of the euamel, and the median pillar is flat on top as if worn by contact of another tooth; but it does not extend as high as the other part of the tooth. In section it is a sharp oval with the narrow part pointing inward. 'This in the third molar is a small pillal euding in a point. There is a minute one between the second and third lobes. The characteristic fold is plainly seen on the third molar, extending from the inuer point of the anterior crescent almost perpendicularly into the mediau valley.

MEASUREMENTS.

Molar 1.

Molar 2. Molar 3.

M.

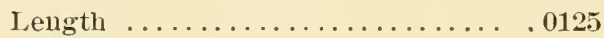

Width $\ldots \ldots \ldots \ldots \ldots \ldots \ldots \ldots \ldots . .610$

Height .................... 006

I.

M.

.014

The depth of the ramus untler the teeth is .016 to .017 M. From Loup Fork beds, lower Madison valley, Montana.

Upper teeth. With the inferior dentition above described I have associated a series of five npper teeth-the molars and last two premolars. They are rery much like the corresponding teeth of Blastomeryx antilopinus Scott, and it may prove to belong to the same species. In size these teeth mateh with those of the lower jaw above described; and there is the same ronghening of the enamel on the molars; but they are rugose on the inside instead of on the outside. The ontside of the molars is more smooth as are also the premolars.

In the molars the transverse diameter is greater than the anteroposterior. On molar 2 the enamel on the internal crescents is perfectly simple except that on the anterior side of the posterior crescent just (xterior to the termination of the posterior horn of the anterior crescent there is a small projection of the enamel towart the prosterorinterior side of the antero-exterual crescent. This descends obliquely and foins the latter. There is a similar pillar on the corresponding part of molar 3 but the enamel does not appear to be continuous with that of the crescent.

Molar 1 is much worn so as to nearly obliterate the enamel lakes. The antero-interior part of the tooth is broken off so the median pillar is not shown. In molar 2 this pillar stands more obliquely than in Cope's representation of Blastomeryx borealis." The pillar is broken on molar 3 , but it is evidently longer than on molar 2 .

*The Artiodactyla Amer. Nat. March, 1899, p. 123. 
ME.ISUREMENTS.

Length of premolar $3 \ldots \ldots \ldots \ldots \ldots \ldots \ldots \ldots \ldots \ldots \ldots \ldots \ldots \ldots .0115$

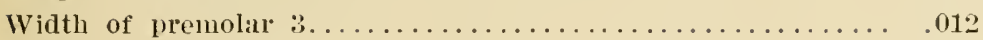

I.ength of premolar $4 \ldots \ldots \ldots \ldots \ldots \ldots \ldots \ldots \ldots \ldots \ldots \ldots \ldots . .010$

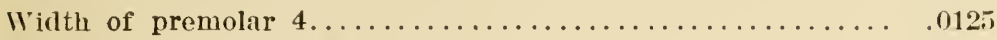

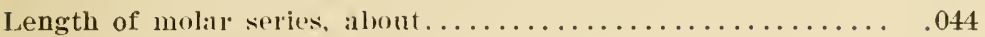

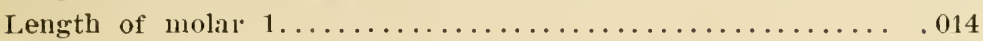

Width of molar $1 \ldots \ldots \ldots \ldots \ldots \ldots \ldots \ldots \ldots \ldots \ldots \ldots \ldots \ldots . .016$

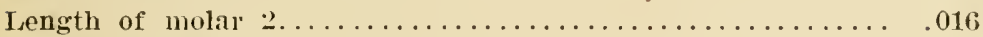

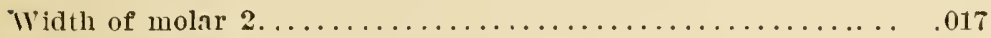

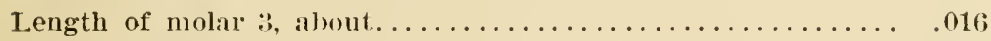

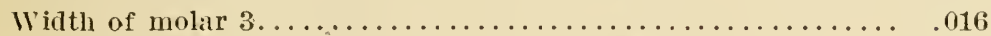

From the Loup Fork leds of the lower Madison.

PALAEOMERYX MADISONIUS, N. SP.

Besides the teeth and jaw described under $P$. americanus 1 have an upper third premolar, and part of a mandible, found in different localities. These belong to a larger species. This is evidently a younger animal than the smaller one just described. The teeth are ligher, leing less worn. The enamel is roughened as in that species. The Palaeomeryx folds are plainly seen on the three molars, which are the only teeth preserved. The median internal pillars are snaller proportionally. There is a small one between the second and third crests of molar 3. This lamus lacks the long depression near the lower border, but there is a broar, shallow concavity on the inner side.

\section{MEASUREMENTS.}

Molar $1 . \quad$ Molar $2 . \quad$ Molar 3. M. M. M.

L.ength, about ............. .013 about .015 about .023

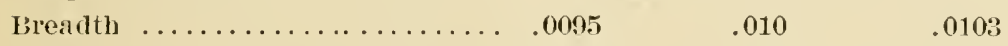

reight $\ldots \ldots \ldots \ldots \ldots \ldots \ldots \ldots \ldots \ldots .0085 \quad .010 \quad .0115$

The upper third premolir differs from the corresponding tooth of $P$. americanus in its greater size and the greater wear has divided the long enamel lake into two smaller ones, and the small lake on the posterior side is narrow, longer. and more erescentic. The association of this tooth with the above described jaw fragment is simple presumption.

\section{COSORYX AGILIS, N. SP,}

Plate IV, Figure 1.

In the bluffs which lie on the eastern side of the lower Madison valley, I found sereral fragments of small animals related to the an. tolopes. Two or three jaw fragments are like Blastomeryx gemmifer 
Cope. Other portions of jaws and horns appear to helong to Cosoryx furcatus Leidy, and $C$. necatus Leidy. In one place I discovered a nearly complete skull, and a complete mandible of a cosoryx which I believe to be a new species. These were associated with a manus and pes, lacking part of the phalanges, a radius and ulna. part of pelvis, three lumber, one sacral and three chrsal rertebrac, portions of ribs ancl other fragments. The animal was young and probably not quite tull grown.

In the sknll both zygomatic arrhes are broken off and the upper part of the face is injured anterior to the orbits. The animal was probably a female, as there are no signs of horns.

The last mper molar had recently protruded and had not ret rearhed the height of the others. On the left side the three temlolary molars had recently been shed and the three permanent ones were all just protruding. The last premolar, which was double, like the true molars, was shed lut canght hotween the upper and lower teeth, from which I removed it. On the right side only the first milk premolal is shed. The next one (premolar $: 3)$ is more triangular than lye last temporary wemolar or the permanent molars; the antero-intorior lobe not being so well developerl. The permanent premolars have each one exterual and one internal clest. In premolar 3 a limb luns outward and lackwarl from the inside of the internal crescent.

The molars are long rertically like those of Antilocapra. The anterior horns of the external crescent to not project quite so strongly but the median rib of the antero-external crescrnt is rery much more prominent, and is large in proportion to the size of the tooth. The orhit is lower than in Antilocapra and is placed farther forward. the anterior horder being above the posterior part of the second molar. I ridge begins at the antero-inferior borler of the orbit, and extends forward branching above the first molar-one branch descending and dying out above premolar 3 , the other extending forward to the mental foramen which is just in frout of a line lassing upward from premolar 2. Ahove this ridge in front of the ere is a coneavity.

The facial racuities were large and ocrupy about the same position as in Antilocapra In the renter of the forehear letween the fiont parts of the orluits is a depression situated somewhat farther forward than the corresponding one in the prong lonck. Bark of this the shape of the skull is very different in the two animals. In Cosoryx, instear of a broad transverse ridge which comnerts the horns, in the former there is a high center sloping gently fore and aft, and slightly less so haterally. Abore the orbit where the hroad rims, which form the roof of the orbit comnert with the other part of the skull, are two elliptical depressions extending in the dirertion of the long axis of the skull. In the posterior part of these depressions open the supra-orbital fora- 
mina which are small. The back of the skull is more romeled, narrower, and proportionally longer than in Antilocapra. From the upper posterior part of the orbit narrow depressions extend backward and unite on the parietal bone halt way betweren the suture which separates that bone from the frontal, and the inion. It their junction a low ridge representing the sagittal crest begins and extends liatk to the oceupit. The npper posterior portion of the skull is more like that of Oreodon than of the deer, prong buck or sheep. It is much like that of the eamel. In Camelus dromedarius the sagittal erest is more strongly dereloped, is longer, the downward slope toward the occiput is not so slarp; and the inion projects more superiorily and posteriorly. In the region of the inion it is almost like the corresponding part of the cat.

The otic bullue are very large as is also the meatus anditorius p.rternus. The orbits are also large and extend outward very prominently.

The lower jaw is complete with all the teetl except the canine and the third incisor of the left side.

The incisors are of nearly the same size and shape, being slightly slatulate or wiler on the eutting edge, which is round and sharp. The canine has nearly the same form but is smaller. It joins the third incisor as in modern ruminants. The disastema is long and the ramus slim beneath. The foramen mentale is situated about onefonrth the distance from incisor 3 to premolar 2. There is another small foramen just forward of premolar 2. It is a little farther forwald on the left than on the right side.

Permanent premolar 2 is just protruding. The other premolars are ot the deciduons set. Temporary premolar 3 is three lobed, as is also premolar 4 which is much longer.

The molars are prismatic and differ little flom those of Antilocapra. The mandible and inferior dentition differ trom scott's description of Cosoryx furcatus * in the following respocts. The mandible is more convex both on the outside and inside than in antiloeapra making the jaw more robust. The valleys of the molars are proportionally as wide and as long as in that genins. The second incisor is slightly the largest. The first molar is as large as the second. The chin is different from seott's figure, not heing at all prominent. The angle is formed by a slight desernt beneath the forman mentale. It then eontinues forward horizontally until it ascents aluputly beloath the ineisors. The foot lomes are neally like those of Blistomerax deseribed ly W. B. Scott. **

*Bull. Inss. of Comp. Zool. 18!6. Vol. XX, No. 8. 1' \$2.

** Ib. page 80 . 
MEASUREMENTS.

M.

I.ength of skull back anterior part of Premolar $2 \ldots \ldots \ldots \ldots . .108$

Length of molar-premolar series, npper............. 045

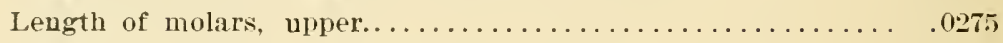

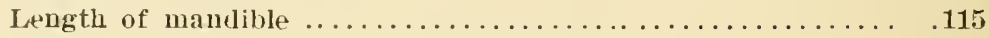

Length of inferior molar premolar series.............. 048

Length of inferior molar series .................. 029

\section{PERISSODACTYLA.}

\section{ACHITHERIUM VON MEYER.}

In my collection from the lower Madison ralley are two specimens consisting of the five upper posterior cheek teeth and a mandibular ramus of another indiridual. The jaw fragment contains the symphysis and the incisors, some of which are broken. I refer both of these fragments to the same species, as they correspond in size, and there is no reason to believe that they belong to separate species. I use . Inchitherium in the restricted sense in which Scott has used it. The Madison species thus being, so far as $I$ know, the second found in America. It is much smaller than $A$. aurelienense Cuv., or $A$. equinum Scott.

\section{ACHITHERIUM MINIMUS, N. SP.}

This species differs from $A$. equinum in the following respects. In upper premolar 3 the cross crests are united by an isthmus across the median valley, this forming two enamel lakes as in the modern horses. This is not the case in premolar 4, and the anterior transverse crosscrest does not reach the outer wall of the crown, but perhaps would on further wear. The posterior pillar is proportionally larger than in scott's specimen. There is a small pillar at the entrance of the metiam valley in premolar 3.

In molar 1 the median transverse cross crest is more sigmoid than in A. equinzm. The posterior pillar is connected with the hypocene. It has a single enamel loop extending outward. The outer erescents have ratler faint median ridges, the anterior being the more prominent.

All the teeth are consirlerably worn except molar 3 , in which the external erescents are unworn, simple, and separated from the exterual ones by deep ralleys. The animal was much smaller than $A$. equinum

\section{MFASUREMFNTS.}

Length of uppor posterior five eheek teeth............. .06i7

Length of upper molar series ..................... 0415 
Length of upper third premolar $\ldots \ldots \ldots \ldots \ldots \ldots \ldots \ldots \ldots \ldots .015$

Wirlth of uppel third premolar ...................... 0194

I.ength of upper fourth premolar ................... 013

Width of upper fourth premolar, about ............... .018

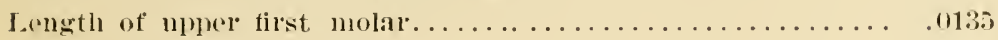

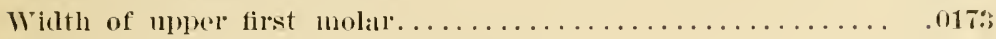

I.ength of upuer second molar, ahout................. .013

Width of npper second molar, about................ 0163

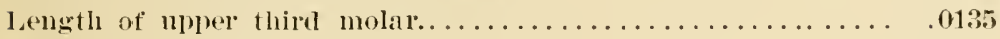

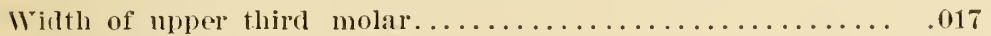

Lower jaw.-The incisors are nearly uniform in size and are semilocmmbent. There is no disastema between the incisors and canine: but the one between the canine and the first premolar is molh longer than in $A$. equinum, both relatively and actually; and the canine is moportionately higher, projecting high above the grinding surface of the incisors. The symphysis is redy long. The alveolar border is elevated above the anterior horder of the jaw. The first premolar is a small. simple, flattened. subconical tooth. In the second premolar there is a slight valley on the anteriol-external side. The tooth is a little more worn than in the specimen of $A$. equinum figured by seott, but is nearly of the same shape. The other premolars and molars are also of nearly the same form.

\section{MEASTREMENTS.}

II.

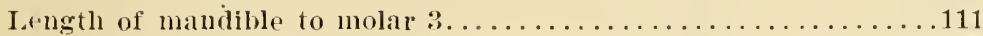

Width of secont lower incisor. . . . . .

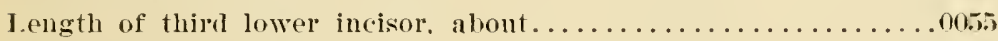

I.ength from canine to premolar I. between alreoli........... . . . . .

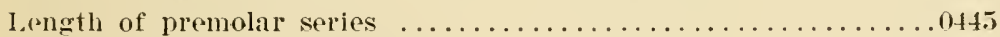

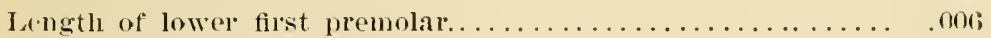

Width of lower first premolar..................... .01:22

Length of second lower premolar................... 0136

Width of lower serond premolar........................

Length of lower third premolar ................... 013

Widtl of lower third premolar ............................ .

Jength of lower fourth premolar. . . . . . . . . . . . . . . .

Wirth of lower fourth premolar.................... 0103

I.ength of lower first molar....................... .

Wientl of lower first molar .......................

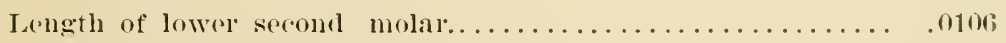

W'ilth of lower second molar.........................

Both the above sperimens were found in the $J$ oup Fork formation in the lower Maclison valley. 


$$
-
$$




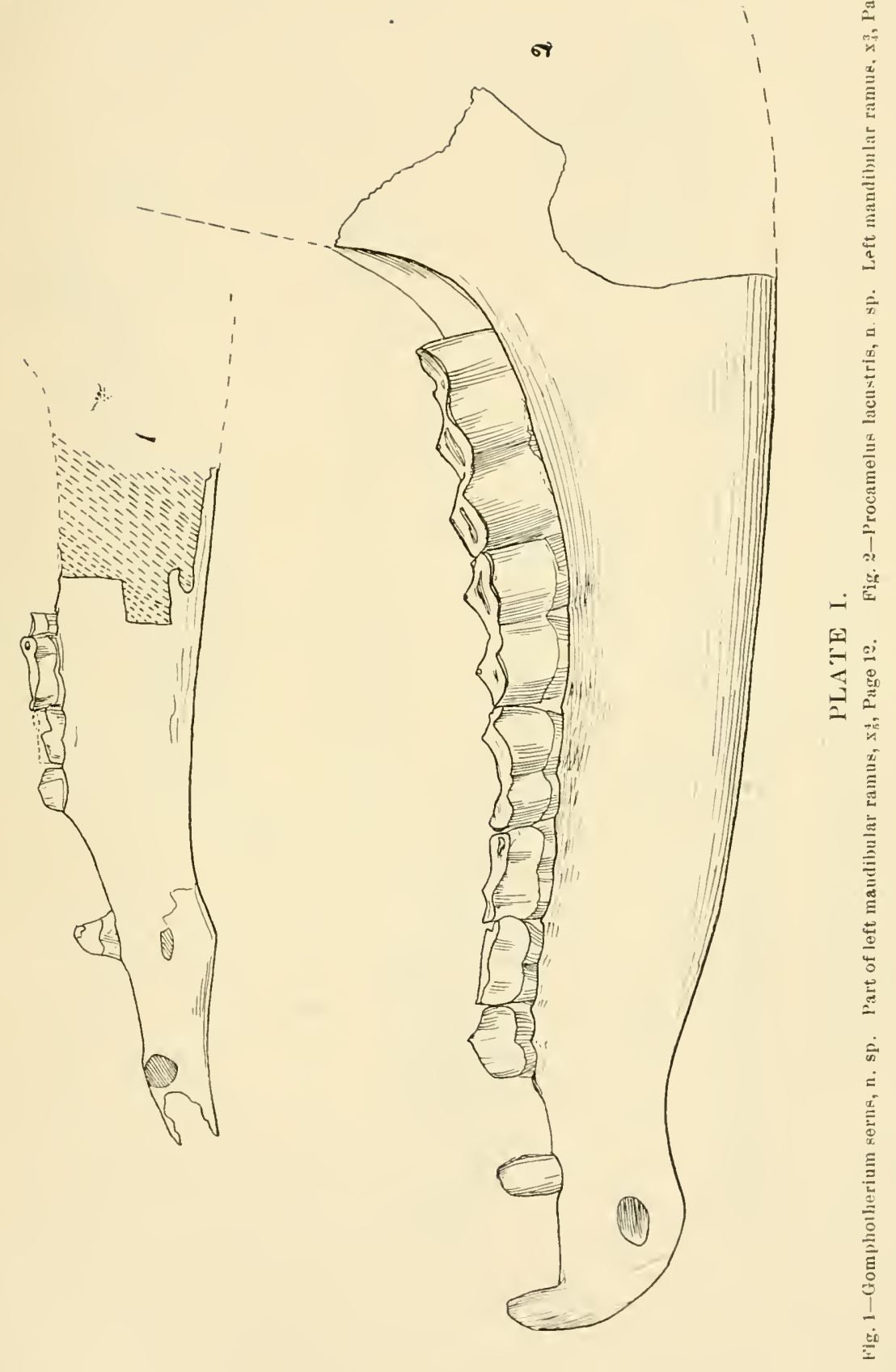





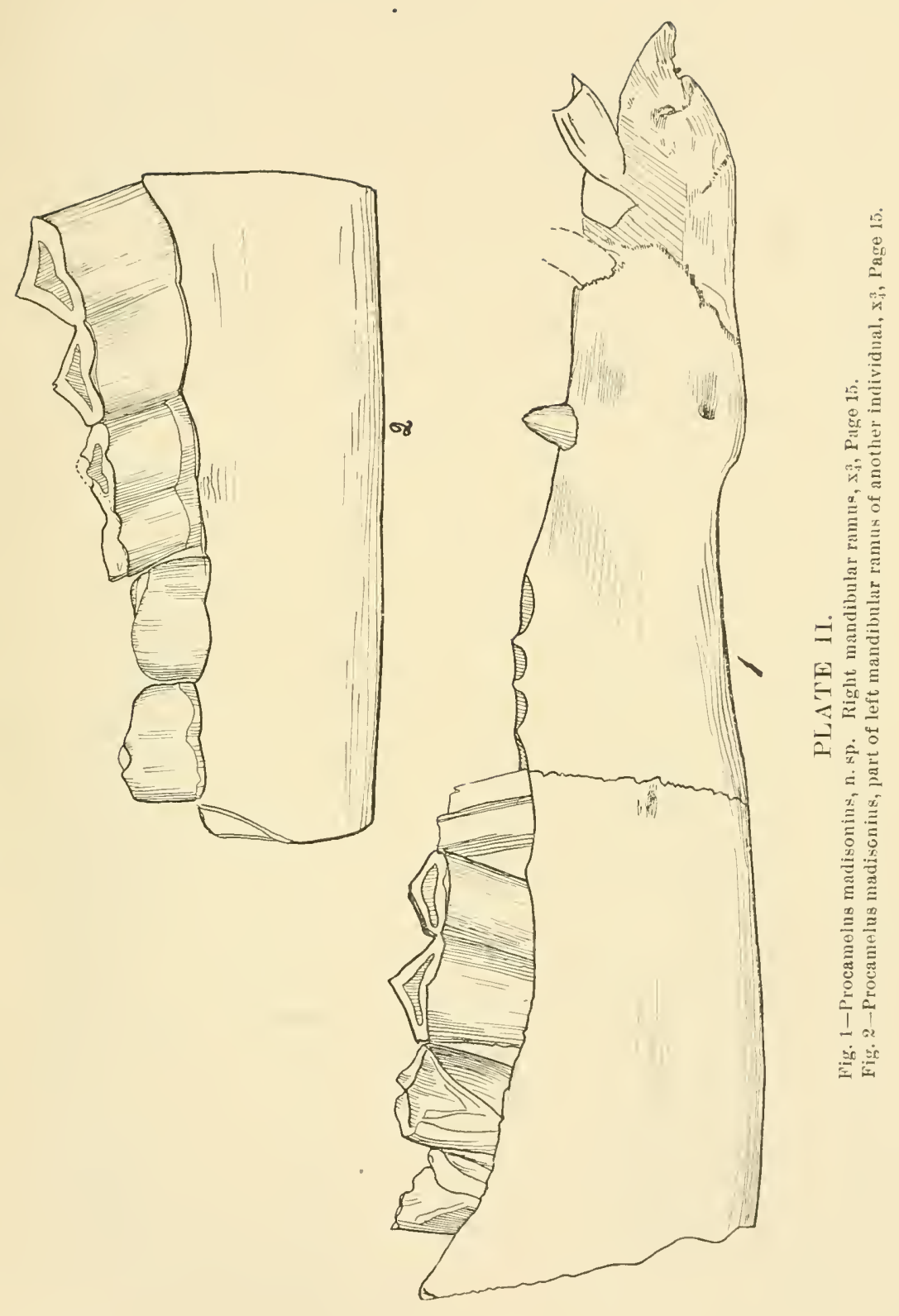




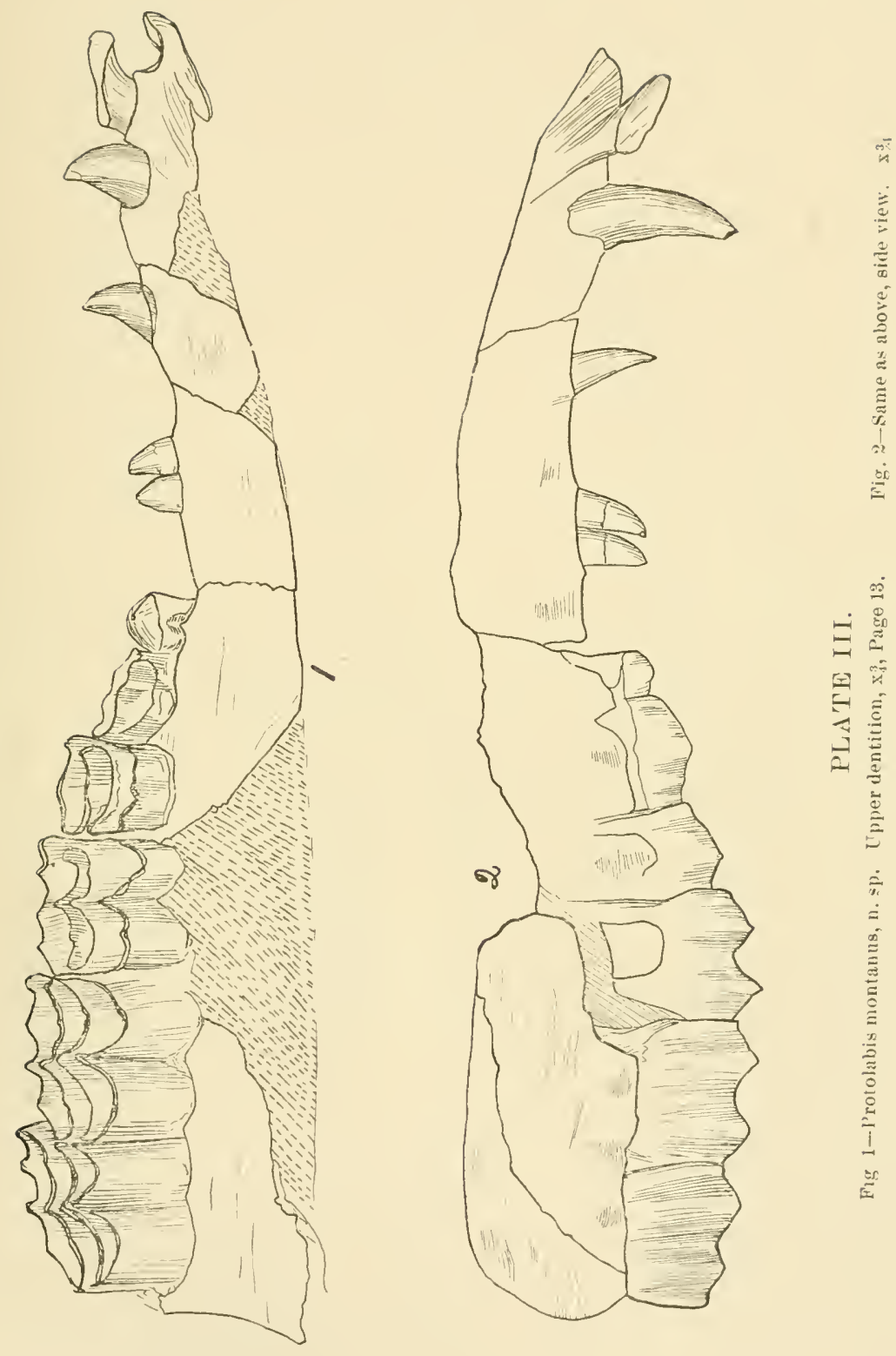

च 


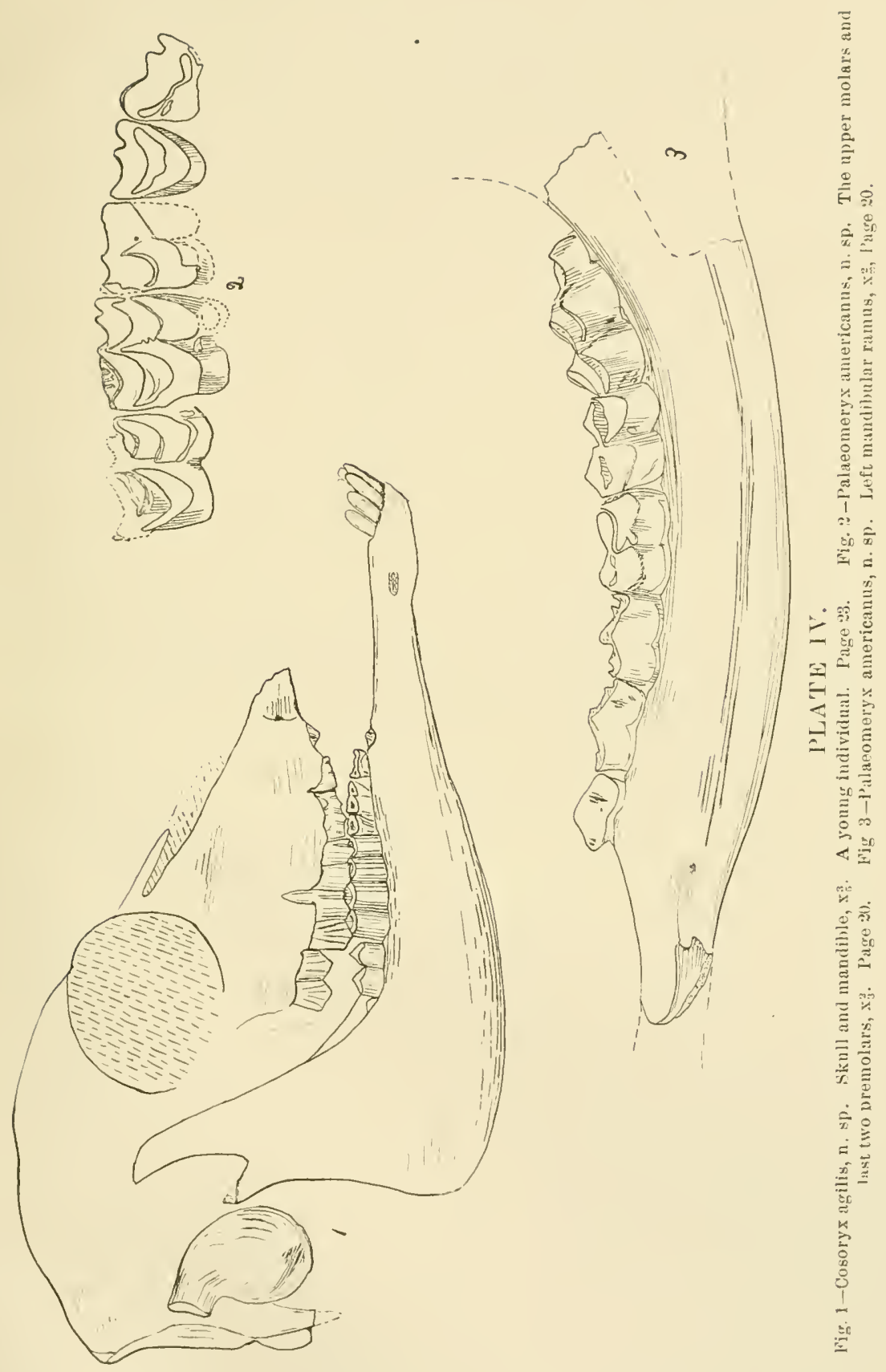





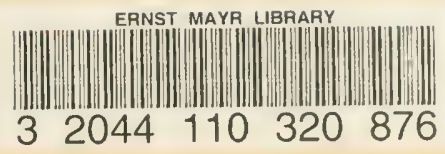




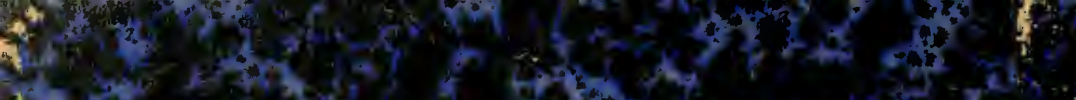
6. $4 x^{4}+x^{2}$

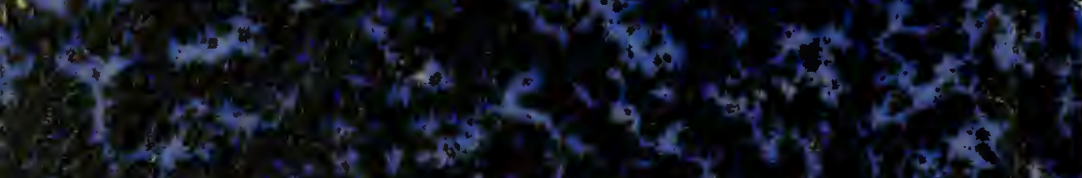
$4 x_{0}+x^{2} x^{2}$.

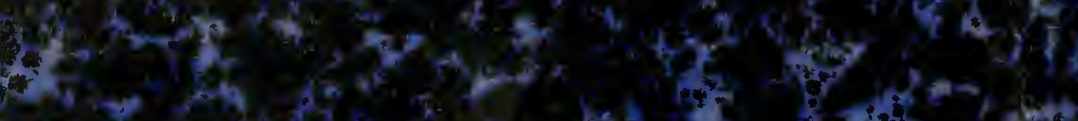

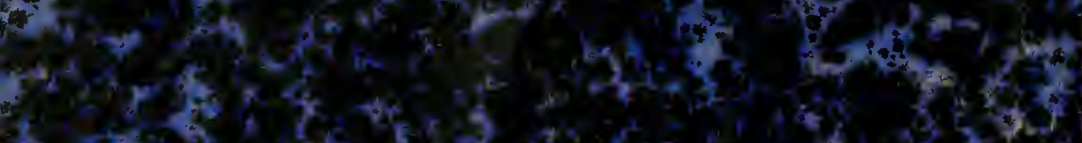

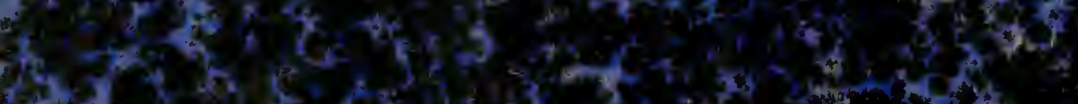

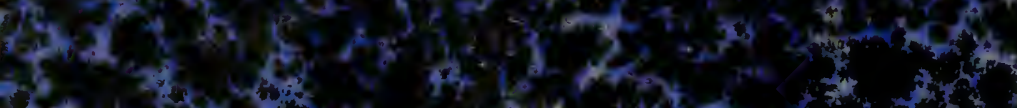

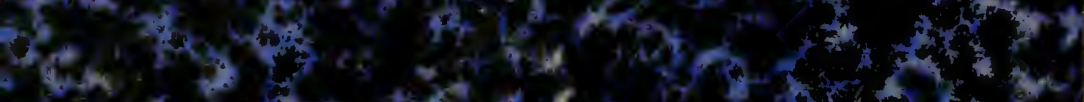

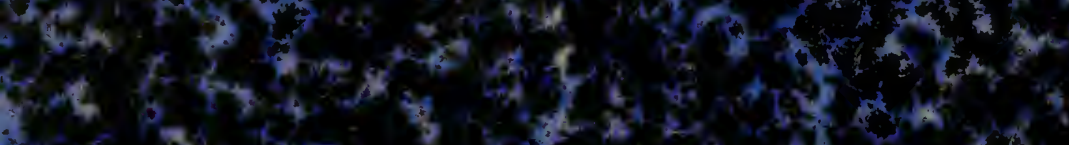
dete $3 x^{2}+x^{2}-2$ to

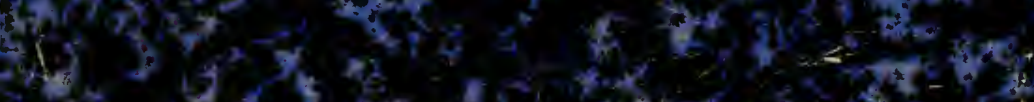

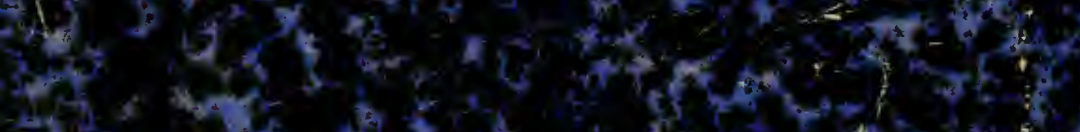
at he pht of

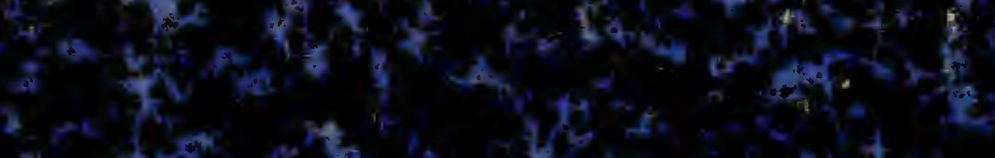

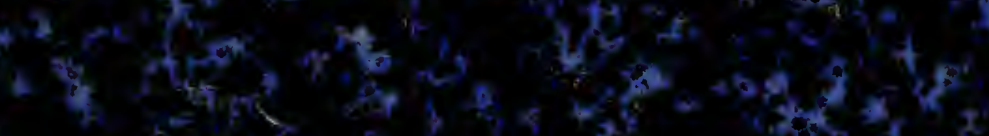

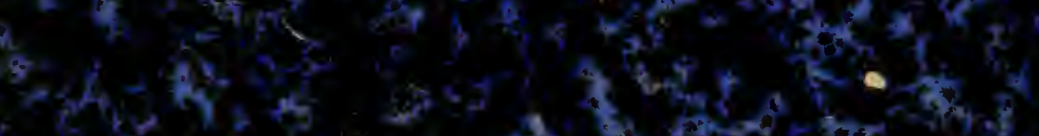

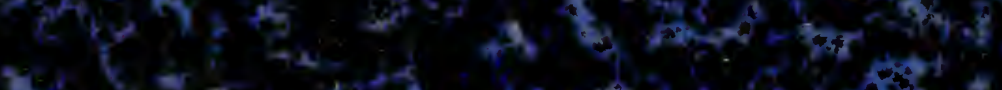

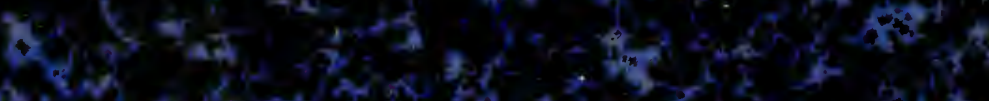
2.0.

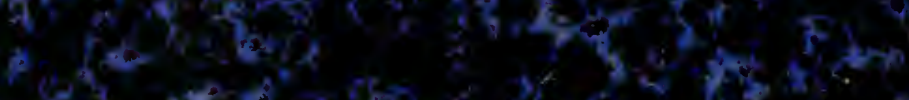

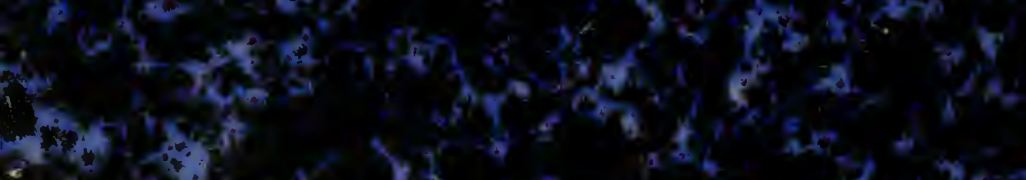
(c)

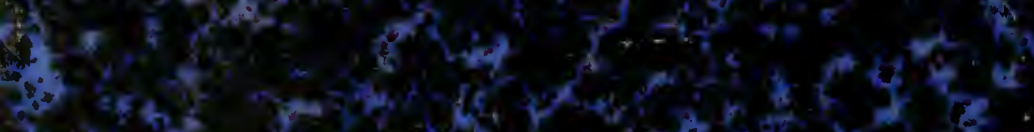

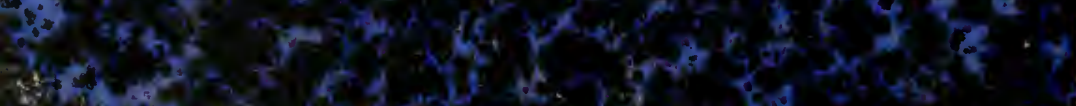

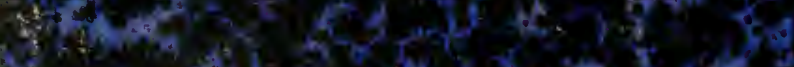

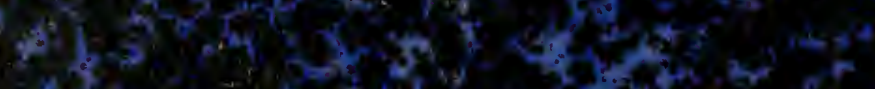

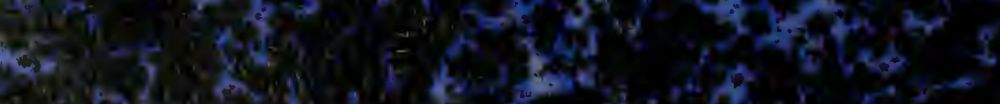

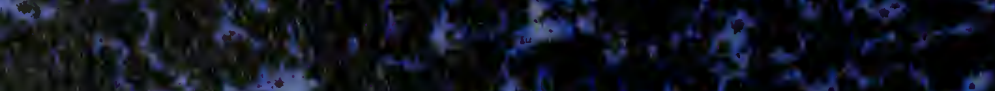

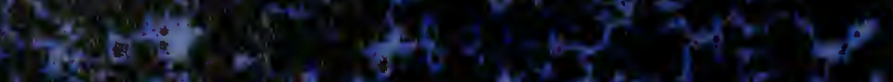

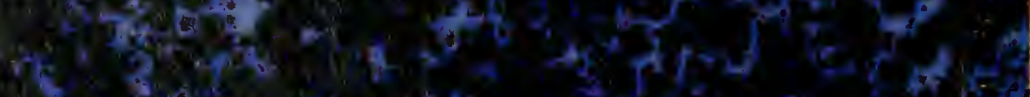
$2 x-5 y-5$ $3 e^{2}, x^{2}$ 